\title{
Diene-Containing Half-Sandwich Mo(III) Complexes as Ethylene Polymerization Catalysts. Experimental and Theoretical Studies
}

Erwan Le Grognec and Rinaldo Poli*

Laboratoire de Synthèse et d'Electrosynthèse Organométalliques, Faculté des Sciences

"Gabriel", Université de Bourgogne, 6 Boulevard Gabriel, 21000 Dijon, France

Correspondence to: Prof. Rinaldo Poli

tel: $+33-03.80 .39 .68 .81$

fax: +33-03.80.39.37.20

E-MAIL: Rinaldo.Poli@u-bourgogne.fr 


\section{Abstract}

Seventeen-electron compounds of $\mathrm{Mo}(\mathrm{III})$ having the general formula $\left(\eta^{5}-\mathrm{C}_{5} \mathrm{R}_{5}\right) \mathrm{Mo}\left(\eta^{4}-\right.$ diene $) \mathrm{X}_{2}\left(\mathrm{R}=\mathrm{H}, \mathrm{Me}\right.$; diene = butadiene, isoprene or 2,3-dimethylbutadiene; $\left.\mathrm{X}=\mathrm{Cl}, \mathrm{CH}_{3}\right)$ are a new class of ethylene polymerization catalysts. The polyethylene obtained shows a bimodal distribution, the major weight fraction being characterized by very long ( $\mathrm{M}$ around $10^{6}$ ) and highly linear polymer chains. The newly prepared pentamethylcyclopentadienyl $\left(\mathrm{Cp}^{*}\right)$ derivatives are more active than the cyclopentadienyl $(\mathrm{Cp})$ derivatives, but much less active than previously investigated niobium(III) compounds having the same stoichiometry. On the other hand, the turnover frequency of the active site leading to the high MW chains is at least 10 times greater than the corresponding $\mathrm{Nb}$ catalyst. The reason for the low activity is explained by a difficult activation process which is attributed to the low polarity and high strength of the Moalkyl bond. This is confirmed by a Mulliken charge analysis of DFT geometry optimized $\mathrm{CpM}\left(\eta^{4}-\mathrm{C}_{4} \mathrm{H}_{6}\right)\left(\mathrm{CH}_{3}\right)_{2}(\mathrm{M}=\mathrm{Nb}, \mathrm{Mo})$ and by the calculation of the heterolytic bond dissociation energies. DFT calculations have also been carried out on the ethylene insertion coordinate for the $\left[\mathrm{CpM}\left(\eta^{4}-\mathrm{C}_{4} \mathrm{H}_{6}\right)\left(\mathrm{CH}_{3}\right)\right]^{+}$model of the presumed active site. The results indicate an equivalent activation barrier to insertion for the $\mathrm{Nb}$ and Mo systems. Differences in optimized geometries for the reaction intermediates are attributed to the presence of the extra electron for the Mo system. This electron opposes the formation of M-H-C agostic interactions while it strengthens the back-bonding M-ethylene interaction, but otherwise plays no active role in the polymer chain propagation mechanism. According to the calculations, the chain propagation for the Mo system occurs entirely on the spin doublet surface, the minimum energy crossover point with the quartet surface lying at a higher energy than the transition state for insertion on the doublet surface.

Keywords: Cyclopentadienyl ligands, Density functional calculations, Ethylene polymerization, Molybdenum, Niobium 


\section{Introduction}

Fundamental research in olefin coordination polymerization (otherwise referred to as Ziegler-Natta polymerization) continues to be one of the major current activities in organometallic chemistry. ${ }^{[1-4]}$ The most recent impulse to this area was given by the independent development by Brookhart and Gibson of paramagnetic iron and cobalt complexes which, in the

presence of the MAO activator, are able to polymerize ethylene with very high activities. ${ }^{[5-8]}$ Together with investigations on catalysts derived from half-sandwich $\mathrm{Cr}(\mathrm{III})^{[9-11]}$ and vanadium in different oxidation states, ${ }^{[12-16]}$ this work represents a departure from the research efforts in metallocene and related catalysts, where the prevalent concept is the development of systems with the same basic architecture (i.e. structure and electron count) of the highly performing Group 4 metallocenes. ${ }^{[2,17-19]}$ Notable examples are $\left(\eta-C_{5} R_{5}\right) 2 \operatorname{LnR}(\operatorname{Ln}=$ lanthanide $),{ }^{[20-24]}$ the so-called constrained-geometry catalysts such as $\left.\mathrm{Me}_{2} \mathrm{Si}_{(} \eta^{5}-\mathrm{C}_{5} \mathrm{Me}_{4}\right)(\mathrm{NR}) \mathrm{MX}_{2}(\mathrm{M}=\mathrm{Ti}, \mathrm{Zr}$, $\mathrm{Hf}),{ }^{[25-28]}$ and $\left(\eta-\mathrm{C}_{5} \mathrm{R}_{5}\right) \mathrm{M}(\eta$-diene $) \mathrm{R}_{2}(\mathrm{M}=\mathrm{Nb}, \mathrm{Ta}),{ }^{[29-31]}$ although many other classes of catalyst precursors have been investigated. In particular, the Brookhart/Gibson catalysts indicate that on going from the 14-electron Fe(II) active site (isoelectronic with the metallocene catalyst active site) to the 15-electron $\mathrm{Co}(\mathrm{II})$ active site, the polymerization activity is not dramatically affected in a negative way. The cobalt catalyst is only slightly less active than the corresponding iron system. ${ }^{[5,7,8]}$

The effect of an additional electron on the catalytic activity in olefin polymerization had been addressed prior to the above mentioned work on $\mathrm{Fe}(\mathrm{II})$ and $\mathrm{Co}$ (II) catalysts. The change of electron count has in some cases been accomplished within the same metal system by a change of metal oxidation state, which is accompanied by a change of charge ${ }^{[32]}$ or ligand environment. ${ }^{[16]}$ Therefore, the conclusions that can be drawn on the effect of the extra electron are not always straightforward. Other comparisons between complexes having the same charge and ligand environment and metals from adjacent groups, like the Brookhart/Gibson Fe/Co pair, have been reported. For instance, while $\left[\mathrm{Cp}_{2} \mathrm{TiR}\right]^{+}$is an active catalyst, $\left[\mathrm{Cp}_{2} \mathrm{VR}\right]^{+}$is unreactive toward 
ethylene ${ }^{[33]}$ and the same seems true for $\left[\mathrm{Cp}_{2} \mathrm{NbR}\right]^{+} .{ }^{[31]}$ A similar difference is found between the isostructural $\mathrm{Cp}_{2}{ }_{2} \mathrm{ScH}$ and $\mathrm{Cp}^{*}{ }_{2} \mathrm{TiH}{ }^{[34]}$ On the other hand, the constrained geometry catalyst derived from $\left[\mathrm{C}_{5} \mathrm{H}_{4}\left(\mathrm{CH}_{2}\right)_{2} \mathrm{NPr}^{\mathrm{i}}\right] \mathrm{VCl}_{2}$ polymerizes ethylene, although with a lower activity and producing polyethylene with considerably lower molecular weight than its Ti(IV) congener. ${ }^{[16]}$ From these reports, it is clear that the role played by an additional electron in the electronic structure of the polymerization catalyst is not well understood and further investigations on this issue are therefore warranted. A theoretical study on rather simplified model systems differing by the $\mathrm{d}^{\mathrm{n}}$ configuration has recently appeared. ${ }^{[35]}$

In this contribution, we compare at the experimental and theoretical levels the halfsandwich $\mathrm{Mo}(\mathrm{III})$ complexes $\mathrm{CpMo}\left(\eta^{4}\right.$-diene) $\mathrm{R}_{2}$ recently developed in our laboratory ${ }^{[36,37]}$ with the corresponding niobium systems previously investigated by Mashima and Nakamura. ${ }^{[29-31]}$ The latter were shown to catalyze the living polymerization of ethylene with moderate activities (up to $35 \mathrm{~kg} \mathrm{~mol}^{-1} \mathrm{~h}^{-1}$ ). Since the unsubstituted CpMo complexes have shown either a very small or no activity, bulkier $\mathrm{Cp}^{*}$ analogues have also been synthesized and are reported here for the first time. These compounds exhibit a very small activity but the polyethylene chains obtained are highly linear and have very high molecular weights, indicating that a difficult activation step generates a very active site which is characterized by an unfavorable chain transfer. The theoretical investigations provide a rationalization for the observed results and illustrate how the additional electron relative to the $\mathrm{Nb}$ system affects the interactions between metal and ligands in the key chain propagation intermediates. These calculations further represent a guiding tool for the future development of new active catalysts based on molybdenum species.

\section{Results}

\section{(a) Syntheses and Characterization of $\mathrm{Cp}^{*} \mathrm{Mo}\left(\eta^{4}-\right.$ diene $)(\mathrm{CH} 3)_{2}$}

By analogy with the synthesis of the corresponding Cp systems, $\left.{ }^{[37,} 38\right]$ compounds

$\mathrm{Cp} * \mathrm{Mo}\left(\eta^{4}\right.$-diene $) \mathrm{Cl}_{2}$ (diene $=$ 2-methylbuta-1,3-diene, 1; 2,3-dimethylbuta-1,3-diene, 2) have 
been prepared by direct addition of the appropriate diene to $\left[\mathrm{Cp} * \mathrm{MoCl}_{2}\right]_{2}$ (see equation 1). Standard alkylation by 2.2 equivalents of $\mathrm{MeMgBr}$ transforms the dichloride compounds $\mathbf{1}$ and $\mathbf{2}$ into the corresponding dimethyl compounds 3 and $\mathbf{4}$ in about $50 \%$ yields, equation 2 .
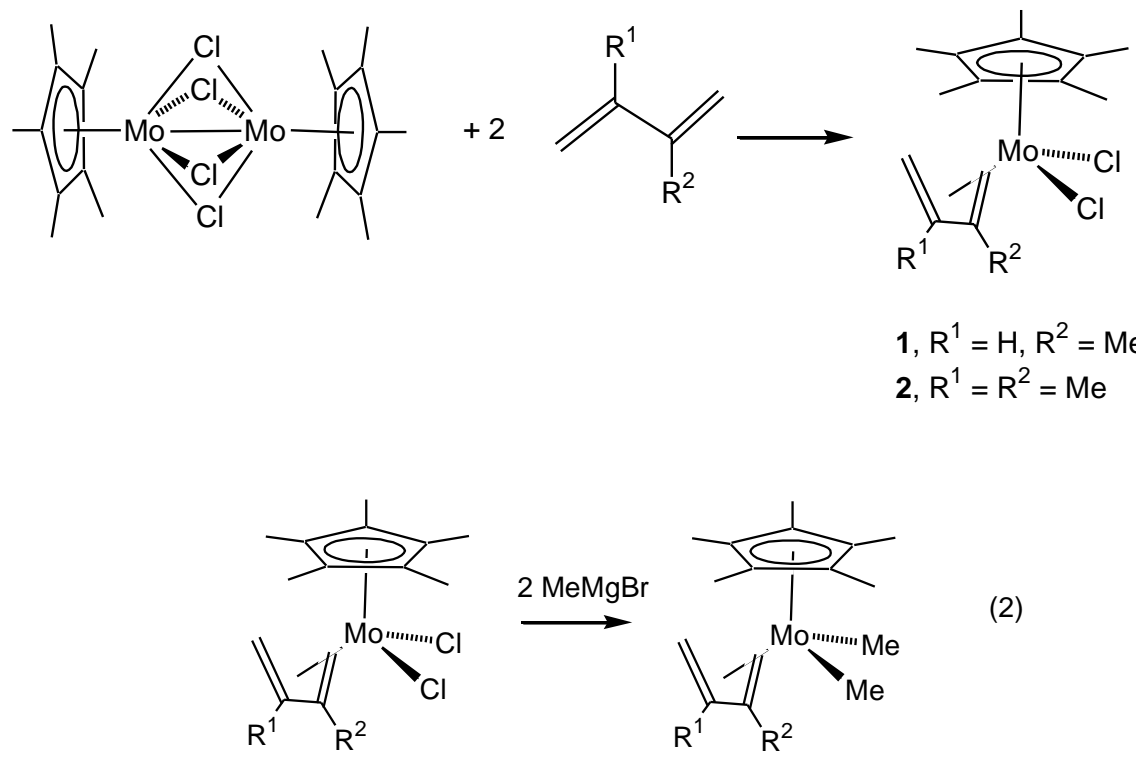

$$
\begin{aligned}
& \text { 3, } R^{1}=H, R^{2}=M e \\
& \text { 4, } R^{1}=R^{2}=M e
\end{aligned}
$$

1, $R^{1}=H, R^{2}=M e$

2, $R^{1}=R^{2}=M e$

Within experimental error, compounds $\mathbf{1}$ and $\mathbf{2}$ show identical EPR properties, as also do compounds 3 and 4. Furthermore, these properties are identical with those previously reported for compounds $\mathrm{CpMo}\left(\eta^{4}\right.$-diene $) \mathrm{Cl}_{2}$ and $\mathrm{CpMo}\left(\eta^{4}\right.$-diene $)\left(\mathrm{CH}_{3}\right)_{2}$, respectively. ${ }^{[36,}$ 37] These observations show that neither the substitution on the diene internal $\mathrm{C}$ atoms nor the substitution on the cyclopentadienyl ring significantly affect the $g$ value and the coupling pattern of the EPR signal.

This class of half-sandwich Mo(III) compounds exhibit redox properties that are highly dependent on the nature of the ligands, ${ }^{[39]}$ thus compounds 1-4 where investigated by cyclic voltammetry. Each compound displays a reversible one-electron reduction wave and a chemically irreversible oxidation wave at the potentials shown in Table 1. All observable trends 
for the reversible $\left(\mathrm{Mo}^{\mathrm{II}} / \mathrm{Mo}^{\mathrm{III}}\right.$ couple) potentials are as expected. All potentials are shifted with respect to the corresponding $\mathrm{Cp}$ complex by ca. $-0.2 \mathrm{~V}$. Analogous shifts were previously reported for other complexes, e.g. $\left[\mathrm{Cp} / \mathrm{Cp}^{*} \mathrm{Mo}\left(\mathrm{PMe}_{3}\right)_{2} \mathrm{I}_{2}\right]^{0 /+} \quad(-0.19 \quad \mathrm{~V})$, $\left[\mathrm{Cp} / \mathrm{Cp} * \mathrm{Mo}\left(\mathrm{PMe}_{3}\right)_{2} \mathrm{Cl}_{2}\right]^{0 /+}(-0.32 \mathrm{~V}),{ }^{[40,}{ }^{41]}\left[\mathrm{Cp} / \mathrm{Cp}^{*} \mathrm{MoCl}\left(\mathrm{PMe}_{3}\right)_{3}\right]^{0 /+}(-0.14 \mathrm{~V}),{ }^{[39]}$ and $\left[\mathrm{Cp} / \mathrm{Cp} * \mathrm{Cr}(\mathrm{NO})\left(\mathrm{PPh}_{3}\right)\right]^{0 /+}(-0.30 \mathrm{~V}){ }^{[42]}$ The substitution of both $\mathrm{Cl}$ ligands by Me groups causes a negative shift of ca. $0.9 \mathrm{~V}$, while a much smaller but significant negative shift is also induced by the additional methyl group on the diene ligand. These shifts are analogous to those of the corresponding Cp systems. ${ }^{[37]}$

Table 1. Redox potentials of compounds 1-4. ${ }^{\mathrm{a}, \mathrm{b}}$

\begin{tabular}{ccc}
\hline $\mathrm{Complex}^{\mathrm{c}}$ & $\mathrm{E}_{1 / 2}\left(\mathrm{Mo}^{\mathrm{II}} / \mathrm{Mo}^{\mathrm{III}}\right) / \mathrm{V}$ & $\mathrm{E}_{\mathrm{p}, \mathrm{a}}\left(\mathrm{Mo}^{\mathrm{III}} / \mathrm{Mo}^{\mathrm{IV}}\right) / \mathrm{V}$ \\
\hline $\mathrm{Cp}{ }^{*} \mathrm{Mo}\left(\eta^{4}-\mathrm{C}_{5} \mathrm{H}_{8}\right) \mathrm{Cl}_{2}, \mathbf{1}$ & $-1.37(-0.18)$ & $0.56(-0.19)$ \\
$\mathrm{Cp} * \mathrm{Mo}\left(\eta^{4}-\mathrm{C}_{6} \mathrm{H}_{10}\right) \mathrm{Cl}_{2}, 2$ & $-1.47(-0.23)$ & $0.50(-0.16)$ \\
$\mathrm{C} \mathrm{p}^{*} \mathrm{Mo}\left(\eta^{4}-\mathrm{C}_{5} \mathrm{H}_{8}\right)\left(\mathrm{CH}_{3}\right)_{2}, 3$ & $-2.27(-0.14)$ & $-0.23(-0.05)$ \\
$\mathrm{Cp} \mathrm{p}^{*} \mathrm{Mo}\left(\eta^{4}-\mathrm{C}_{6} \mathrm{H}_{10}\right)\left(\mathrm{CH}_{3}\right)_{2}, 4$ & $-2.33(-0.19)$ & $-0.27(-0.04)$ \\
\hline
\end{tabular}

${ }^{\mathrm{a}}$ Conditions: THF, $20^{\circ}, 200 \mathrm{mV} \mathrm{s}^{-1}$. ${ }^{\mathrm{b}}$ The values in parentheses are the potential shifts from the corresponding wave of the related $\mathrm{Cp}$ compound under identical conditions, from ref. ${ }^{[37]} .{ }^{\mathrm{c}} \mathrm{C}_{5} \mathrm{H}_{8}$ =2-methylbuta-1,3-diene; $\mathrm{C}_{6} \mathrm{H}_{10}=2,3$-dimethylbuta-1,3-diene

Analogous shifts are observed for the anodic peak potential of the oxidation wave, although the irreversible nature of this process does not in principle allow a correlation with the complexes ground state properties. It is important to remark that no additional waves characteristic of the mixed Cl-Me by-products were observed in the cyclic voltammograms of compounds 3 and 4. As shown previously for the Cp series, ${ }^{[37]}$ these mixed species should exhibit a reduction wave at a potential half-way between those of the dichloro and dimethyl analogues. By EPR, on the other hand, a clear distinction between the signals of the mixed and 
dimethyl species would not be possible. Thus, cyclic voltammetry is the best physical method for assessing the purity of derivatives $\mathbf{3}$ and $\mathbf{4}$.

\section{(b) Catalytic investigations}

The previously reported complexes $\mathrm{CpMo}\left(\eta^{4}\right.$-diene $) \mathrm{X}_{2}$ (diene $=$ buta-1,3-diene, 2,3dimethylbuta-1,3-diene; $\left.\mathrm{X}=\mathrm{Cl}, \mathrm{CH}_{3}\right)^{[37]}$ were tested as ethylene polymerization catalysts in toluene at room temperature in the presence of 1000 equivalents of MAO. In control experiments carried out in the absence of ethylene, the interaction between the dimethyl complex $\mathrm{CpMo}\left(\eta^{4}-\mathrm{C}_{4} \mathrm{H}_{6}\right)\left(\mathrm{CH}_{3}\right)_{2}$ and the excess MAO induces an immediate color change from green to orange. The dichloride compound $\mathrm{CpMo}\left(\eta^{4}-\mathrm{C}_{4} \mathrm{H}_{6}\right) \mathrm{Cl}_{2}$ gives a solution having the same orange color. This color was not persistent, however, slowly evolving toward brown. The rate of this change decreases upon going from the butadiene system to the electron richer and sterically more encumbered 2,3-dimethylbutadiene system. In spite of the above indications of thermal instability, catalytic tests were carried out under 4 bars of ethylene for $1 \mathrm{~h}$ in a transparent glass autoclave as shown in Table 2. The tests with the butadiene complexes (runs 1 and 2) gave no indication whatsoever of polymerization activity. The runs with the 2,3-dimethylbuta-1,3-diene complexes (runs 3-4), on the other hand, showed the development of a faint white turbulence, suggesting the formation of polyethylene. The dichloride compound behaved qualitatively like the corresponding dimethyl compound. The amount of product, however, was largely insufficient in each case to allow isolation, quantification and analysis.

It is know that the catalyst activation is a critical step in Ziegler-Natta polymerization catalysis. The product of the first interaction between the catalyst precursor and the MAO cocatalyst, $\left[\{\mathrm{M}\}{ }^{\cdots} \mathrm{CH}_{3} \cdots \mathrm{MAO}\right]$, is a molecular species or tight ion pair and dissociation into the separate $\{\mathrm{M}\}^{-}$and $\left[\mathrm{CH}_{3}-\mathrm{MAO}\right]^{-}$ions is believed to be required to trigger olefin coordination and polymerization catalysis. It is also well established that an increase of the co-ligands steric bulk facilitates this activation process. ${ }^{[43]}$ The $\mathrm{Cp}^{*}$ compounds were synthesized with this idea in mind. 
Table 2. Ethylene polymerization tests with $\left(\mathrm{C}_{5} \mathrm{R}_{5}\right) \mathrm{Mo}\left(\eta^{4}\right.$-diene $) \mathrm{X}_{2} / \mathrm{MAO}(1: 1000)$ in toluene $(60 \mathrm{~mL})$ at $20^{\circ} \mathrm{C}$.

\begin{tabular}{ccccccc}
\hline Run & Compound $^{\mathrm{a}}$ & $\begin{array}{c}\text { Amount } \\
(\mathrm{mg})\end{array}$ & $\begin{array}{c}\mathrm{P}\left(\mathrm{C}_{2} \mathrm{H}_{4}\right) \\
(\mathrm{atm})\end{array}$ & $\begin{array}{c}\mathrm{t} \\
(\mathrm{h})\end{array}$ & $\begin{array}{c}\mathrm{PE} \\
(\mathrm{mg})\end{array}$ & $\begin{array}{c}\text { Activity } \\
\left(\mathrm{Kg}(\mathrm{PE}) \mathrm{mole}^{-1} \mathrm{~atm}^{-1} \mathrm{~h}^{-1}\right)\end{array}$ \\
\hline 1 & $\mathrm{CpMo}\left(\eta^{4}-\mathrm{C}_{4} \mathrm{H}_{6}\right) \mathrm{Cl}_{2}$ & 25 & 4 & 1 & - & - \\
2 & $\mathrm{CpMo}\left(\eta^{4}-\mathrm{C}_{4} \mathrm{H}_{6}\right)\left(\mathrm{CH}_{3}\right)_{2}$ & 25 & 4 & 1 & - & - \\
3 & $\mathrm{CpMo}\left(\eta^{4}-\mathrm{C}_{6} \mathrm{H}_{10}\right) \mathrm{Cl}_{2}$ & 25 & 4 & 1 & traces & $\mathrm{b}$ \\
4 & $\mathrm{CpMo}\left(\eta^{4}-\mathrm{C}_{6} \mathrm{H}_{10}\right)\left(\mathrm{CH}_{3}\right)_{2}$ & 20 & 4 & 1 & $\operatorname{traces}$ & $\mathrm{b}$ \\
5 & $\mathbf{1}$ & 20 & 4 & 1 & $\operatorname{traces}$ & $\mathrm{b}$ \\
6 & $\mathbf{2}$ & 20 & 4 & 1 & $\operatorname{traces}$ & $\mathrm{b}$ \\
7 & $\mathbf{4}$ & 20 & 4 & 1 & $\operatorname{traces}$ & $\mathrm{b}$ \\
8 & $\mathbf{2}$ & 42 & 50 & 1 & 35.5 & 0.019 \\
9 & $\mathbf{2}$ & 59 & 50 & 2 & 95.6 & 0.010 \\
10 & $\mathbf{2}$ & 72 & 50 & 3 & 127.2 & 0.013 \\
\hline
\end{tabular}

${ }^{\mathrm{a}} \mathrm{C}_{4} \mathrm{H}_{6}=$ buta-1,3-diene; $\mathrm{C}_{5} \mathrm{H}_{8}=2$-methylbuta-1,3-diene; $\mathrm{C}_{6} \mathrm{H}_{10}=$ 2,3-dimethylbuta-1,3-diene.

${ }^{b}$ Estimated upper limit for the catalytic activity: $0.1 \mathrm{Kg}(\mathrm{PE}) \mathrm{mole}^{-1} \mathrm{~atm}^{-1} \mathrm{~h}^{-1}$.

Compounds 1, 2 and 4 interact with MAO to afford orange solutions which appear more stable than those obtained from the $\mathrm{Cp}$-substituted complexes. The exposure of these solutions to ethylene does indeed qualitatively indicate the formation of a greater amount of polymer when the reactions are carried out under the same conditions in the glass autoclave at low ethylene pressure (runs 5, 6 and 7). Again, no qualitative difference between the dichloride and dimethyl analogues $\mathbf{2}$ and $\mathbf{4}$ was noted. The amount of polymer formed, however, remains too low for the isolation of sufficiently pure materials for analysis. A sufficient amount of polymer for isolation and characterization were eventually obtained upon carrying out the catalytic runs at a greater ethylene pressure in a stainless steel autoclave (runs 8-10). 
Although the activity of these catalytic systems are quite low $\left(<0.02 \mathrm{Kg} \mathrm{mole}^{-1} \mathrm{~atm}^{-1} \mathrm{~h}^{-1}\right)$, several features appear rather interesting. First, the catalyst seems to remain active over a time scale of 4 hours, the activity being approximately the same for the 1,2 , and $4 \mathrm{~h}$ runs. Secondly, all three polymer samples are shown by IR spectroscopy to be highly crystalline and highly linear. Particularly informative are the split band at $720 \mathrm{~cm}^{-1}$ which is characteristic of highly crystalline domains and the very weak band at $1378 \mathrm{~cm}^{-1}$ indicating a very small degree of branching. Thirdly, all three samples are shown by the GPC analysis to contain a bimodal distribution - more or less identical for the three runs - which includes extremely high molecular weight chains (distribution centered around ca. $10^{6}$ ) as the preponderant fraction in weight, plus a fraction of shorter chains (distribution centered around $10^{4}$ ), see



Figure 1. The differential scanning calorimetric analysis shows again the same behavior for the three polyethylene samples, with melting point at $133-134^{\circ}$ and $\Delta \mathrm{H}$ in the range 194-215 J $\mathrm{g}^{-1}$. These values are typical of highly linear, high-density polyethylene. ${ }^{[44]}$ While a value of $135^{\circ} \mathrm{C}$ is indicated for the ideal "linear" homopolymer, a degree of branching as low as 1 chain $/ 1000 \mathrm{C}$ causes a sharp melting point decrease to less than $130^{\circ} \mathrm{C}$. The heat of fusion, in comparison with the standard reference of ca. $280 \mathrm{~J} \mathrm{~g}^{-1}$ for linear polyethylene, ${ }^{[44]}$ indicates a 
degree of crystallinity around 70-75\%. Had the molecular weight distribution been less dispersed, this value would certainly be even greater.

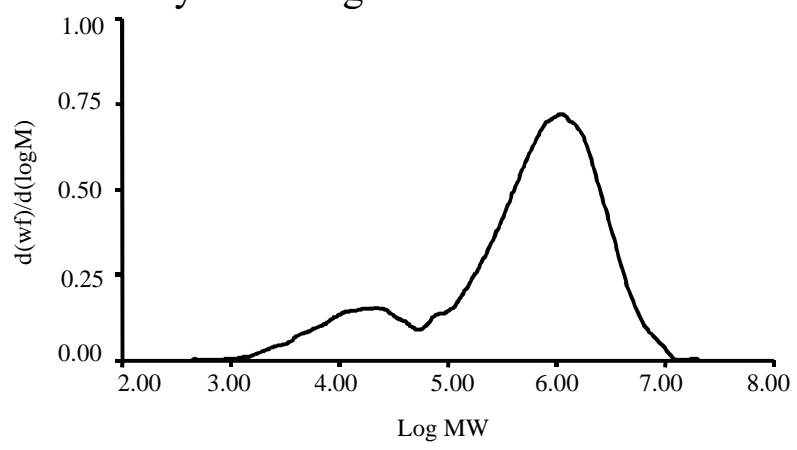

Figure 1. GPC trace of polyethylene obtained from run 10 (Table 2). Solvent $=1,2,4-$ trichlorobenzene. $\mathrm{T}=135^{\circ} \mathrm{C}$.

Our interpretation of these results is that only a small fraction of the catalyst is activated by the MAO, to yield at least two different kinds of active sites. It is not excluded that one (secondary) active site is obtained by the slow decomposition of the main site during the long polymerization runs. This is in fact suggested by the behavior of the [Mo]/MAO solutions in the absence of ethylene (vide supra). The very long and higly linear polymer chains are consistent with very little chain transfer, if any. A calculation of the average turnover for the long chains, under the hypothesis of no termination, yields $10 \mathrm{~s}^{-1}$ (on the basis of the most probable molecular weight of $10^{6}$ ), corresponding to a maximum activation free energy of $16 \mathrm{kcal} \mathrm{mol}^{-1}$ for the rate determining step of the chain growth process. Obviously, the TOF is even greater if chain transfer occurs. On the other hand, a rough calculation from the mass of isolated polymer and the estimated number of chains shows that a very small fraction $(<0.1 \%)$ of the molybdenum centers are catalytically active.

It is most interesting to compare the polymerization results obtained with compound $\mathbf{2}$ with those of its $\mathrm{Nb}$ congener. The niobium system was shown to have living character and to give polymers with $\mathrm{M}_{\mathrm{n}}$ up to $10^{5}$ in $1 \mathrm{~h}$ runs at $20^{\circ}{ }^{[31]}$ This corresponds to an insertion turnover of ca. $1 \mathrm{~s}^{-1}$. Therefore, although the overall catalytic activity is at least $10^{3}$ times greater for the $\mathrm{Nb}$ 
system, the activity of an active site is at least 10 times greater for the Mo system (active site leading to the heavier chains).

To conclude the experimental part of our investigation, we have shown that the Mo system $\left(\mathrm{C}_{5} \mathrm{R}_{5}\right) \mathrm{Mo}\left(\eta^{4}\right.$-diene $) \mathrm{X}_{2}$ is indeed able to initiate and carry out Ziegler-Natta ethylene polymerization, although the catalyst stability is low for the less encumbered complexes and the activities are much smaller then those of the corresponding $\mathrm{Nb}$ systems. ${ }^{[31]}$ The reason for this lower activity appears to be linked to the catalyst activation step. This proposition has been further probed by the computational work described in the following section. 


\section{(c) Computational studies}

(c1) The 17-electron catalyst precursor and the methyl abstraction step. The calculations were carried out with the B3LYP functional and the standard LANL2DZ basis set, which is suitable for middle size organometallic systems and has given good quantitative results in our own recent work. ${ }^{[45-52]}$ Calculations were first carried out on models of the dimethyl catalyst precursors, $\mathrm{CpM}\left(\eta^{4}-\mathrm{C}_{4} \mathrm{H}_{6}\right)\left(\mathrm{CH}_{3}\right)_{2}(\mathrm{M}=\mathrm{Mo}, \mathrm{Nb})$. Both compounds have been fully optimized without any symmetry constraints, yielding the results in 
Table 3. The Mo optimized structure is compared with that experimentally determined for the 2,3-dimethylbuta-1,3-diene analogue. ${ }^{[37]}$ The excellent agreement between optimized and experimental parameters attests to the suitability of this computational level and, at the same time, to the negligible effect of the two diene methyl substituents on the optimum binding parameter of the diene and the other ligands.

An experimentally determined structure does not appear to be available in the literature for the $\mathrm{Nb}$ system, therefore the quality of the optimization cannot be directly evaluated. However, the observed changes are as one would expect from the known differences of metal properties. The smaller radius of $\mathrm{Mo}^{\mathrm{III}}$ relative to $\mathrm{Nb}^{\mathrm{III}}$ accounts for the observed shortening of all M-ligand bonds on going from $\mathrm{Nb}$ to Mo. Niobium, being an earlier metal, is expected to have a better $\pi$ donating ability because of higher energy d orbitals. This phenomenon can be witnessed in the larger negative $\Delta \mathrm{d}^{[53]}$ value for the $\mathrm{Nb}$ complex and in the variations in the diene $\mathrm{C}-\mathrm{C}$ bond lengths, the internal one becoming longer and the external ones becoming shorter on going from $\mathrm{Nb}$ to Mo. The calculations support the conclusion ${ }^{[37]}$ based on the experimental structure that back-bonding is relatively important also for the Mo compound (internal C-C bond shorter than the external ones). According to the Yasuda-Nakamura $\Delta \mathrm{d}-\theta$ correlation, ${ }^{[53]}$ however, both $\mathrm{Nb}$ and Mo systems are more appropriately described as $\mathrm{M}^{\mathrm{III}}$-diene complexes rather then as $\mathrm{M}^{\mathrm{V}}$ but-2-ene-1,4-diyl complexes. 
Table 3. Relevant structural parameters for compounds $\mathrm{CpM}\left(\eta^{4}-\mathrm{C}_{4} \mathrm{H}_{6}\right)\left(\mathrm{CH}_{3}\right)_{2}(\mathrm{M}=\mathrm{Nb}, \mathrm{Mo})$ (distances in $\AA$, angles in degrees, Mulliken charges q in fractional units)

\begin{tabular}{|c|c|c|c|}
\hline \multirow[t]{2}{*}{ Parameter } & \multirow{2}{*}{$\begin{array}{c}\mathrm{CpNb}\left(\eta^{4}-\mathrm{C}_{4} \mathrm{H}_{6}\right)\left(\mathrm{CH}_{3}\right)_{2} \\
\text { optimized }\end{array}$} & \multicolumn{2}{|c|}{$\mathrm{CpMo}\left(\eta^{4}-\mathrm{C}_{4} \mathrm{H}_{6}\right)\left(\mathrm{CH}_{3}\right)_{2}$} \\
\hline & & optimized & experimental $^{\mathrm{a}}$ \\
\hline $\mathrm{M}-\mathrm{CNT}(1)^{\mathrm{b}}$ & 2.224 & 2.123 & $2.020(5)$ \\
\hline $\mathrm{M}-\mathrm{CNT}(2)^{\mathrm{c}}$ & 2.016 & 1.942 & $1.926(3)$ \\
\hline \multirow[t]{2}{*}{ M-C(diene, external) } & 2.313 & 2.280 & $2.231(4)$ \\
\hline & 2.311 & 2.292 & $2.221(3)$ \\
\hline \multirow[t]{2}{*}{ M-C(diene, internal) } & 2.445 & 2.358 & $2.362(2)$ \\
\hline & 2.444 & 2.367 & $2.335(2)$ \\
\hline \multirow[t]{2}{*}{$\mathrm{M}-\mathrm{CH}_{3}$} & 2.236 & 2.225 & $2.229(5)$ \\
\hline & 2.236 & 2.225 & $2.217(9)$ \\
\hline \multirow[t]{2}{*}{ C-C (diene, external) } & 1.455 & 1.443 & $1.426(2)$ \\
\hline & 1.455 & 1.440 & $1.426(7)$ \\
\hline C-C (diene, internal) & 1.406 & 1.419 & $1.394(3)$ \\
\hline CNT(1)-M-CNT(2) & 135.70 & 139.03 & $136.1(6)$ \\
\hline \multirow[t]{2}{*}{$\mathrm{CNT}(1)-\mathrm{M}-\mathrm{CH}_{3}$} & 112.21 & 111.96 & $111.9(7)$ \\
\hline & 111.78 & 112.31 & $112.7(3)$ \\
\hline \multirow[t]{2}{*}{$\mathrm{CNT}(2)-\mathrm{M}-\mathrm{CH}_{3}$} & 99.38 & 99.90 & $101.1(2)$ \\
\hline & 99.58 & 98.77 & $100.9(2)$ \\
\hline$\Delta \mathrm{d}^{\mathrm{d}}$ & -0.132 & -0.0765 & -0.1225 \\
\hline$\theta^{\mathrm{e}}$ & 93.60 & 92.80 & 93.80 \\
\hline $\mathrm{q}(\mathrm{M})$ & 1.031 & 0.533 & \\
\hline$q(C p)^{f}$ & -0.128 & -0.018 & \\
\hline $\mathrm{q}\left(\mathrm{CH}_{3}\right)^{\mathrm{f}}$ & -0.311 & -0.228 & \\
\hline$q\left(\mathrm{CH}_{2}, \text { diene }\right)^{\mathrm{f}, \mathrm{g}}$ & -0.170 & -0.089 & \\
\hline $\mathrm{q}(\mathrm{CH}, \text { diene })^{\mathrm{f}, \mathrm{g}}$ & 0.029 & 0.059 & \\
\hline
\end{tabular}

${ }^{\mathrm{a}}$ For compound $\mathrm{CpMo}\left(\eta^{4}-\mathrm{C}_{6} \mathrm{H}_{8}\right)\left(\mathrm{CH}_{3}\right) 2$, see ref. ${ }^{[37]}$. ${ }^{\mathrm{b}} \mathrm{CNT}(1)$ : cyclopentadienyl ring centroid. ${ }^{\mathrm{c}} \mathrm{CNT}(2)$ : butadiene ligand centroid. ${ }^{\mathrm{d}} \Delta \mathrm{d}=[\mathrm{d}(\mathrm{M}-\mathrm{C} 1)+\mathrm{d}(\mathrm{M}-\mathrm{C} 4)-\mathrm{d}(\mathrm{M}-\mathrm{C} 2)-\mathrm{d}(\mathrm{M}-\mathrm{C} 3)] / 2 .{ }^{[53]}{ }^{\mathrm{e}}{ }_{\theta}=$ dihedral angle between the $\mathrm{C} 1-\mathrm{M}-\mathrm{C} 4$ and $\mathrm{C} 1-\mathrm{C} 2-\mathrm{C} 3-\mathrm{C} 4$ planes. ${ }^{[53]} \mathrm{f}_{\text {Total }}$ group charge.

$\mathrm{g}_{\text {Average on the two equivalent groups. }}$

The theoretical calculations yield the group Mulliken charges shown in Table 3. Although the absolute values of these charges should be taken with caution, the observed variations for a 
family of similar compounds provide reliable trends. As expected from the lower electronegativity of $\mathrm{Nb}$, this compound yields a greater positive charge for the metal center and a greater negative (or smaller positive) charge for all ligands relative to the compound of the more electronegative molybdenum. As a consequence, the $\mathrm{M}-\mathrm{CH}_{3}$ bonds are significantly less polarized for the Mo compound. The polarity difference suggests that the catalyst activation step, namely the alkyl abstraction by the MAO co-catalyst, will be substantially more difficult for the Mo system. Incidentally, this difference also accounts for the previously reported inertness of the $\mathrm{CpMo}\left(\eta^{4}-\mathrm{C}_{4} \mathrm{H}_{6}\right)\left(\mathrm{CH}_{3}\right)_{2}$ compound toward relatively strong Brønsted acids. ${ }^{[37]}$ We can therefore propose that the adduct between the $\mathrm{Mo}^{\mathrm{III}}$ complex and the MAO activator, $\left\{[\mathrm{M}]{ }^{\cdots} \mathrm{CH}_{3} \cdots \mathrm{MAO}\right\}$, displays a greater resistance toward ion separation with respect to the $\mathrm{Nb}$ analogue. Preliminary studies of the interaction between $\mathrm{CpMo}\left(\eta^{4}-\mathrm{C}_{4} \mathrm{H}_{6}\right)\left(\mathrm{CH}_{3}\right)_{2}$ and $\mathrm{B}\left(\mathrm{C}_{6} \mathrm{~F}_{5}\right)_{3}$, which will be reported in a separate contribution, ${ }^{[54]}$ fully confirm this hypothesis. It may also be argued that the MAO reagent could attack the butadiene ligand rather than one of the Mo-X bonds $\left(\mathrm{X}=\mathrm{Cl}\right.$ or $\left.\mathrm{CH}_{3}\right),{ }^{[30,31,55]}$ given that the addition of Lewis acids to butadiene ligands is documented in the literature. ${ }^{[56]}$ As unlikely as this event may seem in the presence of Mo-X bonds, we do not have so far any solid evidence to rule it out. The interaction between the dialkyl complexes and $\mathrm{B}\left(\mathrm{C}_{6} \mathrm{~F}_{5}\right)_{3}$, however, eventually leads to the identification of a methyl abstraction product, which forms only with difficulty. ${ }^{[54]}$

Under the continued assumption that the activation step involves methyl abstraction by MAO we have investigated theoretically the heterolytic $\mathrm{M}-\mathrm{CH}_{3}$ bond strengths for complexes $\mathrm{CpMo}\left(\eta^{4}-\mathrm{C}_{4} \mathrm{H}_{6}\right)\left(\mathrm{CH}_{3}\right)_{2}(\mathrm{M}=\mathrm{Mo}, \mathrm{Nb})$, as shown in Scheme 1. Marks and Fragalà have shown the importance of the metal-alkyl bond strengths in the thermodynamic cycle which regulates the catalyst activation step. ${ }^{[28,57-59]}$ This process yields a model of the "active species", $\left[\mathrm{CpM}\left(\eta^{4}-\right.\right.$ $\left.\left.\mathrm{C}_{4} \mathrm{H}_{6}\right)\left(\mathrm{CH}_{3}\right)\right]^{+}$. We would like to believe that this is a model for the active site that leads to the longer polymer chains. The demonstration of this statement will require, however, further experimental investigations. The energy results shown in Scheme 1 confirm the predictions made on the basis of the Mulliken charge analysis. The heterolysis of the $\mathrm{Mo}^{-} \mathrm{CH}_{3}$ bond requires 
almost 10 additional $\mathrm{kcal} / \mathrm{mol}$ than that of the corresponding $\mathrm{Nb}-\mathrm{CH}_{3}$ bond. The optimized geometries of the "active species" $\left[\mathrm{CpM}\left(\mathrm{C}_{4} \mathrm{H}_{6}\right)\left(\mathrm{CH}_{3}\right)\right]^{+}$are discussed in the next section.

Scheme 1

$$
\begin{aligned}
& \mathrm{CpM}\left(\mathrm{C}_{4} \mathrm{H}_{6}\right)\left(\mathrm{CH}_{3}\right)_{2} \longrightarrow\left[\mathrm{CpM}\left(\mathrm{C}_{4} \mathrm{H}_{6}\right)\left(\mathrm{CH}_{3}\right)\right]^{+}+\mathrm{CH}_{3}^{-} \\
& \Delta \mathrm{E}= 200.78 \mathrm{kcal} / \mathrm{mol}(\mathrm{Mo}) \\
& 191.30 \mathrm{kcal} / \mathrm{mol}(\mathrm{Nb})
\end{aligned}
$$

(c2) The ethylene insertion coordinate. The above calculations seem to confirm that the lower Mo activity relative to the $\mathrm{Nb}$ complex is attributable to the activation step. However, we were also interested in analyzing theoretically the chain propagation process and to compare the energetic barrier with that of the more active $\mathrm{Nb}$ system. Extensive theoretical studies have been reported for a variety of other polymerization catalysts, covering all relevant features including

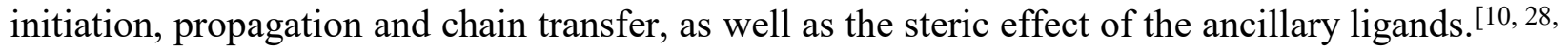
60-73] In particular, a recent study by Lanza et al. illustrates that the ion pair separation process becomes more favorable after the initial methyl group has been turned into a longer alkyl chain. ${ }^{[28]}$ This is consistent with our observed high activity of a small fraction of the metal centers, after a difficult activation step. Therefore, we did not deem it necessary to exhaustively investigate all relevant geometries along the reaction coordinate, plus solvent and steric effects. Rather, we have restricted our study to the basic chain propagation step whereby an ethylene molecule coordinates to the metal center and inserts into a $\mathrm{M}-\mathrm{CH}_{3}$ bond to afford a $\mathrm{M}$ $\mathrm{CH}_{2} \mathrm{CH}_{2} \mathrm{CH}_{3}$ moiety. However, an additional point of interest is the possible intervention of a spin state change for the Mo-catalyzed process, to involve spin quartet 15-electron intermediates. We have shown that other half-sandwich 15-electron Mo(III) reaction intermediates adopt a spin quartet ground state ${ }^{[74,75]}$ and that, in a particular case, ${ }^{[76]}$ the Minimum Energy Crossing Point (MECP) between the doublet and quartet spin surfaces leading to these intermediates lies lower in energy than the asymptote along the spin doublet surface, resulting in a spin acceleration phenomenon. ${ }^{[77,78]}$ Theoretical calculations on the Brookhart/Gibson catalysts also indicate the 
possible involvement of more than one spin state along the olefin polymerization process. ${ }^{[72,79]}$ Therefore, we have extended our study to both spin doublet and quartet hypersurfaces for the Mo system, including the MECP.

To simplify the discussion, the critical geometries are identified by the letters $\mathbf{A}, \mathbf{B}, \mathbf{C}$ and $\mathbf{D}$

according to Scheme 2. For the Mo system, an additional lower case letter $\mathbf{d}$ or $\mathbf{q}$ identifies the spin state. When an agostic interaction is present, this is indicated in parentheses by the position at which this occurs, e.g. ( $\alpha$ ). Complex A models the supposed active catalyst. Complex $\mathbf{B}$ is the $\pi$ complex which forms upon addition of an ethylene molecule, and $\mathbf{C}$ is the transition state between $\mathbf{B}$ and $\mathbf{D}$, the latter being the insertion product. The geometry of all species has been optimized without any symmetry constraint. The energetic results are shown in

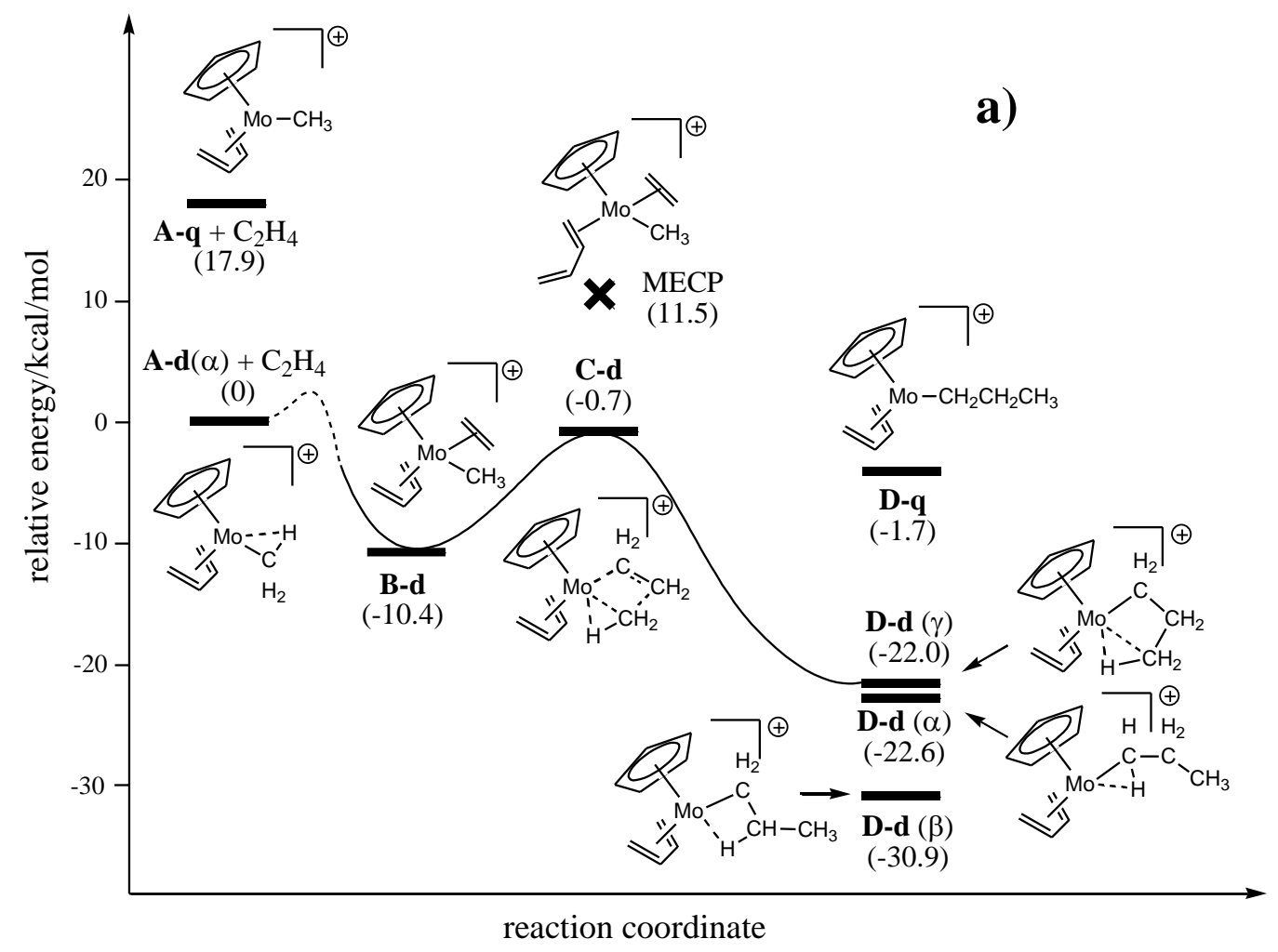




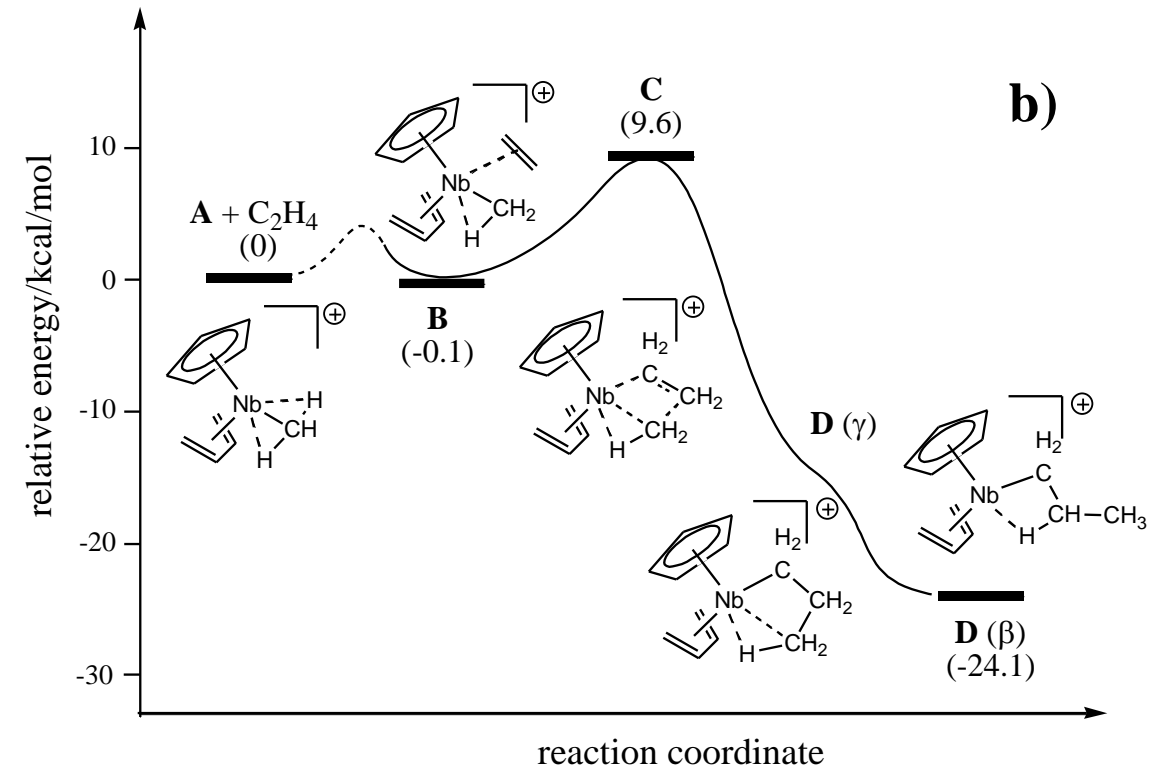

Figure 2 and the relevant optimized parameters are collected in Table 4 and 
Table 5 for the Mo and $\mathrm{Nb}$ systems, respectively. Fractional coordinates of all optimized structures are available as Supporting Information.

Scheme 2

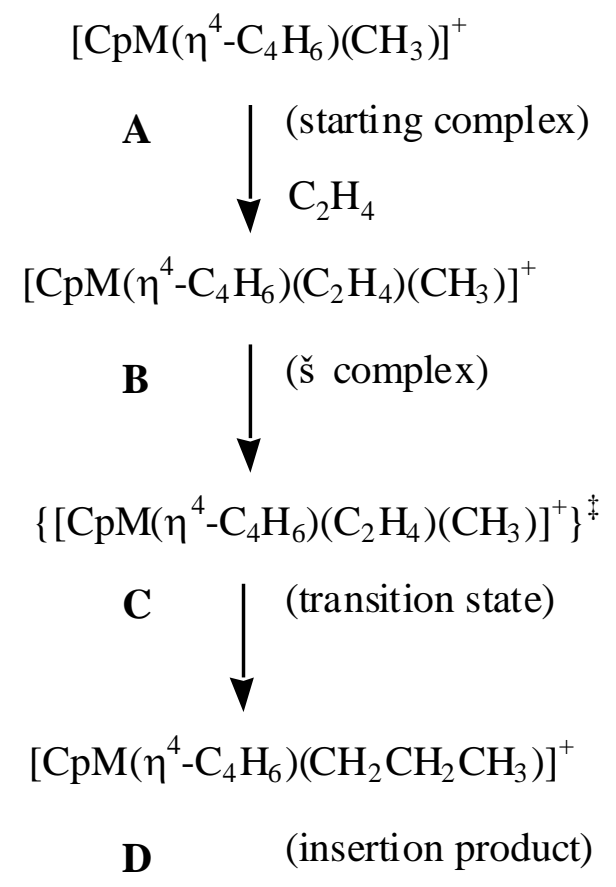



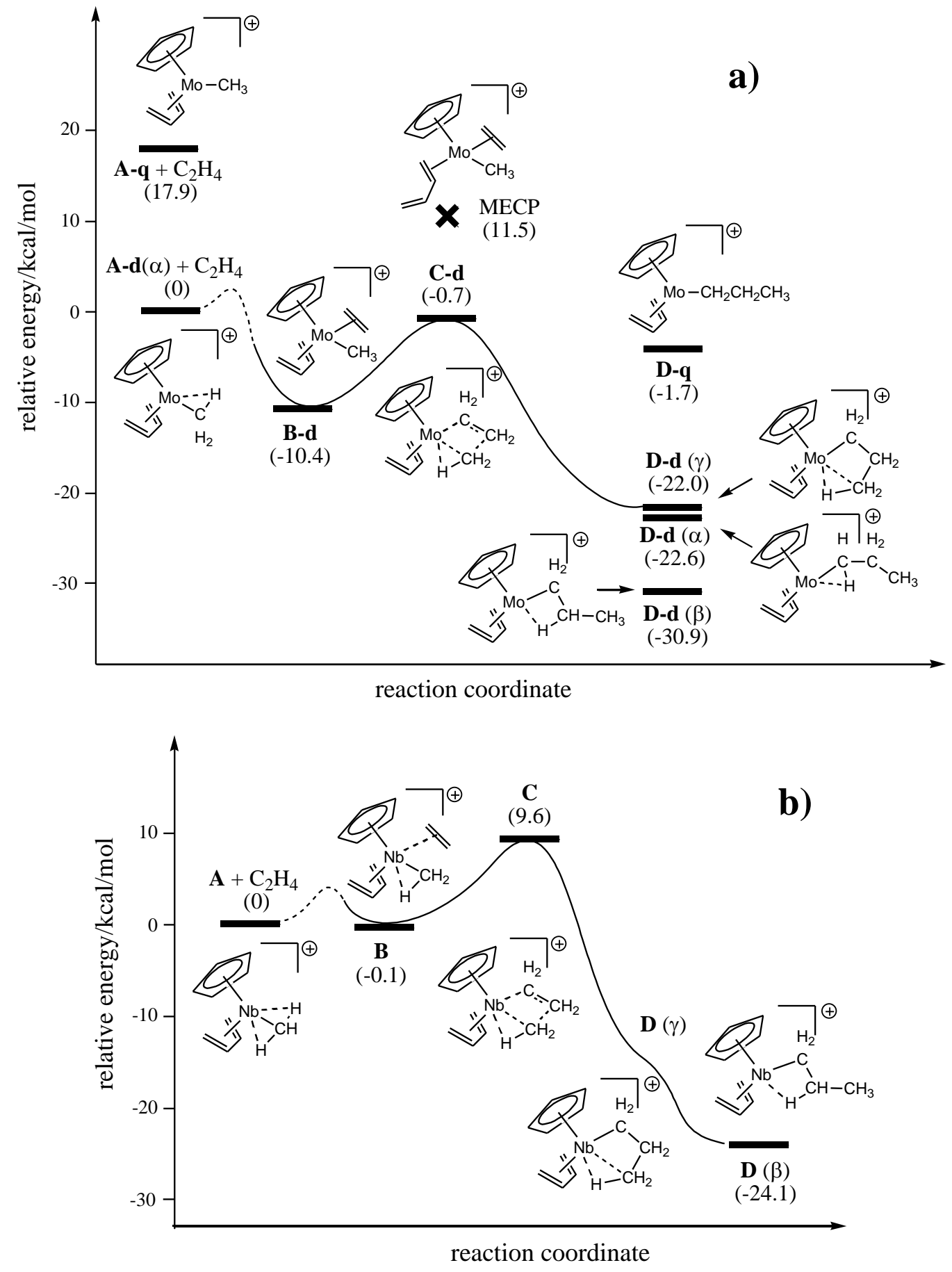

Figure 2. Energy diagram and key structures for the ethylene insertion reaction into the $\mathrm{Mo}_{-} \mathrm{CH}_{3}$ bond of $\left[\mathrm{CpMo}\left(\eta^{4}-\mathrm{C}_{4} \mathrm{H}_{6}\right)\left(\mathrm{CH}_{3}\right)\right]^{+}$. 
Table 4. Relevant structural parameters for species A, B, C and D with $\mathrm{M}=$ Mo (distances in $\AA$, angles in degrees) $)^{\mathrm{a}}$

\begin{tabular}{|c|c|c|c|c|c|c|c|c|}
\hline & $\operatorname{A-d}(\alpha)$ & A-q & B-d & C-d & D-d( $(\alpha)$ & D-d( $\beta)$ & D-d $(\gamma)$ & D-q \\
\hline Mo-C1 & 2.107 & 2.160 & 2.236 & 2.432 & - & - & 3.030 & - \\
\hline Mo-C2 & - & - & 2.715 & 2.574 & - & 2.552 & - & - \\
\hline Mo-C3 & - & - & 2.646 & 2.258 & 2.096 & 2.177 & 2.179 & 2.171 \\
\hline $\mathrm{C} 1-\mathrm{C} 2$ & - & - & 2.868 & 2.118 & 1.550 & 1.544 & 1.555 & 1.549 \\
\hline $\mathrm{C} 2-\mathrm{C} 3$ & - & - & 1.372 & 1.439 & 1.532 & 1.515 & 1.548 & 1.548 \\
\hline \multirow[t]{2}{*}{ diene $C-C(e x t)$} & 1.448 & 1.382 & 1.439 & 1.436 & 1.442 & 1.439 & 1.448 & 1.383 \\
\hline & 1.437 & 1.383 & 1.428 & 1.426 & 1.437 & 1.426 & 1.430 & 1.386 \\
\hline diene $\mathrm{C}-\mathrm{C}$ & 1.421 & 1.477 & 1.423 & 1.425 & 1.423 & 1.427 & 1.423 & 1.474 \\
\hline (int) & & & & & & & & \\
\hline Mo-C3-C2 & - & - & 62.82 & 85.20 & 132.28 & 85.45 & 104.04 & 114.22 \\
\hline $\mathrm{C} 1-\mathrm{C} 2-\mathrm{C} 3$ & - & - & 115.62 & 120.33 & 112.31 & 116.55 & 112.15 & 112.12 \\
\hline Mo ${ }^{\cdots} \mathrm{H}$ & 2.422 & $\mathrm{~b}$ & $\mathrm{~b}$ & 2.487 & 2.151 & 2.049 & 2.451 & $\mathrm{~b}$ \\
\hline $\mathrm{C}-\mathrm{H}$ & 1.124 & $\mathrm{c}$ & $\mathrm{c}$ & 1.097 & 1.158 & 1.174 & 1.113 & $\mathrm{c}$ \\
\hline Mo $\cdots \mathrm{H}-\mathrm{C}$ & 60.39 & - & - & 74.32 & 71.55 & 101.20 & 110.83 & - \\
\hline
\end{tabular}

${ }^{\mathrm{a}}$ Numbering scheme used: $\mathrm{C} 1=$ carbon atom of the migrating $\mathrm{CH}_{3}$ group; $\mathrm{C} 2=$ atom to which $\mathrm{C} 1$ migrates; $\mathrm{C} 3=$ atom forming the Mo- $\mathrm{C} \sigma$ bond; $\mathrm{H}=$ agostic hydrogen atom. ${ }^{\mathrm{b}}$ Minimum Mo ${ }^{\cdots} \mathrm{H}$ distance to nonagostic $\mathrm{H}$ atoms of the $\mathrm{Mo}-\mathrm{CH}_{\mathrm{n}}$ group: 2.742 for $\mathbf{A - q}, 2.778$ for B-d, 2.701 for D-q. ${ }^{\mathrm{C}}$ Maximum $\mathrm{C}-\mathrm{H}$ distance to nonagostic $\mathrm{H}$ atoms of the $\mathrm{Mo}-\mathrm{CH}_{\mathrm{n}}$ group: 1.100 for A-q, 1.098 for B-d, 1.104 for D-q. 
Table 5. Relevant structural parameters for species A, B, C and D with $\mathrm{M}=\mathrm{Nb}$ (distances in $\AA$, angles in degrees) ${ }^{\mathrm{a}}$

\begin{tabular}{lcccc}
\hline & $\mathbf{A}$ & $\mathbf{B}$ & $\mathbf{C}$ & $\mathbf{D}(\boldsymbol{\beta})$ \\
\hline $\mathrm{Nb}-\mathrm{C} 1$ & 2.119 & 2.160 & 2.290 & - \\
$\mathrm{Nb}-\mathrm{C} 2$ & - & 3.185 & 2.630 & 2.690 \\
$\mathrm{Nb}-\mathrm{C} 3$ & - & 3.343 & 2.363 & 2.144 \\
$\mathrm{C} 1-\mathrm{C} 2$ & - & 3.299 & 2.132 & 1.545 \\
$\mathrm{C} 2-\mathrm{C} 3$ & - & 1.356 & 1.429 & 1.538 \\
diene C-C(ext) & 1.466 & 1.458 & 1.449 & 1.461 \\
& 1.466 & 1.466 & 1.452 & 1.457 \\
diene C-C & 1.410 & 1.408 & 1.410 & 1.411 \\
(int) & & & & \\
$\mathrm{Nb}-\mathrm{C} 3-\mathrm{C} 2$ & - & 71.55 & 83.97 & 92.38 \\
$\mathrm{C} 1-\mathrm{C} 2-\mathrm{C} 3$ & - & 80.61 & 118.31 & 114.28 \\
$\mathrm{Nb} \cdots \mathrm{H}$ & $2.602^{\mathrm{b}}$ & 2.546 & 2.201 & 2.302 \\
$\mathrm{C}-\mathrm{H}$ & $1.109^{\mathrm{c}}$ & 1.113 & 1.128 & 1.136 \\
$\mathrm{Nb} \cdots \mathrm{H}-\mathrm{C}$ & $52.53^{\mathrm{d}}$ & 57.37 & 79.85 & 97.05 \\
\hline
\end{tabular}

${ }^{\mathrm{a}}$ Numbering scheme as in Table 4. ${ }^{\mathrm{b}}$ Identical for two methyl $\mathrm{H}$ atoms; the third $\mathrm{H}$ atom is at $2.869 \AA$ from the $\mathrm{Nb}$ center. ${ }^{\mathrm{c}}$ Identical for the two agostic $\mathrm{H}$ atoms; the third $\mathrm{C}-\mathrm{H}$ distance is $1.091 \AA$. didentical for the two agostic $\mathrm{H}$ atoms; the third $\mathrm{Nb}^{\cdots} \mathrm{H}-\mathrm{C}$ angle is $38.04^{\circ}$.

We shall discuss the results pertaining to the Mo system first, and then compare them with the $\mathrm{Nb}$ analogue. The starting complex $\mathbf{A}$ is calculated as more stable in the doublet state. Unlike the quartet, the doublet benefits of an agostic interaction which certainly contributes energetically to its stabilization. The analysis of the insertion process along the doublet surface suggests that the propagation should indeed be a very facile process. Coordination of ethylene is exothermic as expected. The energetic barrier to 
this coordination process leading from $\mathbf{A - d}(\boldsymbol{\alpha})$ to $\mathbf{B}-\mathbf{d}$ (as indicated by the broken segment of the coordinate in
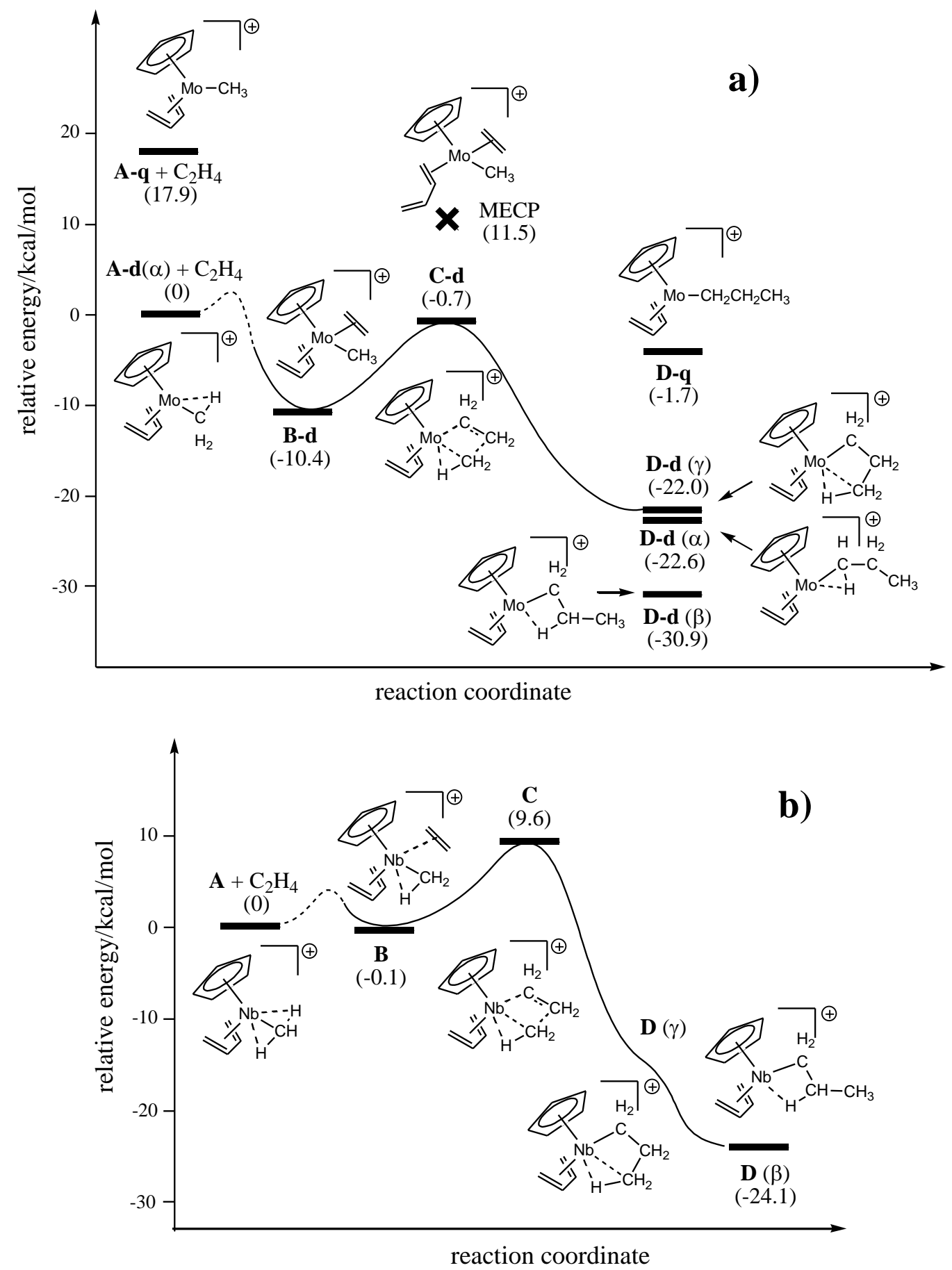

Figure 2a) was not calculated. Previous studies have shown that this step proceeds without an enthalpic barrier for metallocene type systems, even when stronger $\beta$-agostic interactions are 
present. $^{[80]}$ The insertion step leading to the agostic propyl product D-d( $\left.\gamma\right)$ has a calculated barrier of $9.7 \mathrm{kcal} / \mathrm{mole}$, and is exothermic by $11.6 \mathrm{kcal} / \mathrm{mol}$. Although the barrier is greater than that calculated for the efficient zirconocene catalysts, it is quite similar to that of others efficient systems (e.g. $10.5 \mathrm{kcal} / \mathrm{mol}$ for the nickel diimine system ${ }^{[63]}$ ) and is lower than the upper limit obtained from the crude polymer analysis (vide supra). It has also been shown by MO/MM studies that the steric effect of bulky ligands lowers this activation barrier. ${ }^{[67,72,79,81]}$ Therefore, the calculations are consistent with $\left[\mathrm{CpMo}\left(\eta^{4}-\mathrm{C}_{4} \mathrm{H}_{6}\right) \mathrm{R}\right]^{+}$being a good model for one of the catalytically active sites for our 2/MAO system. As is generally found, the relative stability of the agostic propyl product goes as $\beta>>\alpha>\gamma$. It can be seen from the parameters in Table 4 that this trend parallels the strength of the agostic interaction (a greater stabilization is associated with shorter $\mathrm{Mo}{ }^{\cdots} \mathrm{H}$ and longer $\mathrm{C}-\mathrm{H}$ distances for the agostic $\mathrm{H}$ atom). From the data in Table 4, it can also be concluded that the transition state $\mathbf{C}$-d is neither a very early nor a very late one, and its agostic interaction is a very weak one at best. We have not determined the barrier of interconversion between the different agostic isomers. The $\beta$-agostic isomer will probably readily form before further ethylene coordination takes place. By comparison with the $\mathbf{A}-\mathbf{d}(\boldsymbol{\alpha})$ to B-d transformation, it is predictable that further coordination of ethylene to complex $\mathbf{D}-\mathbf{d}(\boldsymbol{\beta})$ will be exothermic by ca. $2 \mathrm{kcal} / \mathrm{mol}$ and, as argued above, should have a small or nonexisting barrier.

Like complex A, complex $\mathbf{D}$ is also calculated as more stable in the doublet state. Species D-q is $20.3 \mathrm{kcal} / \mathrm{mol}$ less stable than $\mathbf{D}-\mathbf{d}(\boldsymbol{\gamma})$ and $20.9 \mathrm{kcal} / \mathrm{mol}$ less stable than $\mathbf{D}-\mathbf{d}(\boldsymbol{\alpha})$. This latter difference is substantially greater than that between $\mathbf{A}-\mathbf{q}$ and $\mathbf{A}-\mathbf{d}(\boldsymbol{\alpha})$. A possible explanation can be found in the optimized parameters of Table 4. The ethyl substituent on the $\alpha$ $\mathrm{C}$ atom in $\mathbf{D}-\mathbf{d}(\alpha)$ is forced away from the metal (large Mo-C3-C2 angle), forcing in turn one of the $\mathrm{H}$ atoms closer to the Mo center (shorter $\mathrm{Mo}{ }^{\cdots} \mathrm{H}$ contact) and thereby establishing a stronger agostic interaction. This is also evidenced by the longer C-H bond in D-d( $\alpha)$ relative to A-d( $\alpha)$. A stronger $\alpha$-agostic interaction for an ethyl $v s$. a methyl group has been verified experimentally for a hydrotris(pyrazolyl)borate derivative of Ta(III). ${ }^{[82]}$ 
As both the starting complex $\mathbf{A}$ and the final product $\mathbf{D}$ have higher energies in the quartet state than the transition state to insertion on the doublet surface, C-d, we did not investigate the insertion process along the quartet surface. However, we carried out an MECP calculation starting from the $\mathbf{C}$-d geometry. This calculation converges to a geometry that has no resemblance to a structure involved in a propagation step of ethylene polymerization, with a relative energy of $11.5 \mathrm{kcal} / \mathrm{mol}$ relative to $\mathbf{A}-\mathbf{d}(\boldsymbol{\alpha})+\mathrm{C}_{2} \mathrm{H}_{4}$ (point marked with a cross in

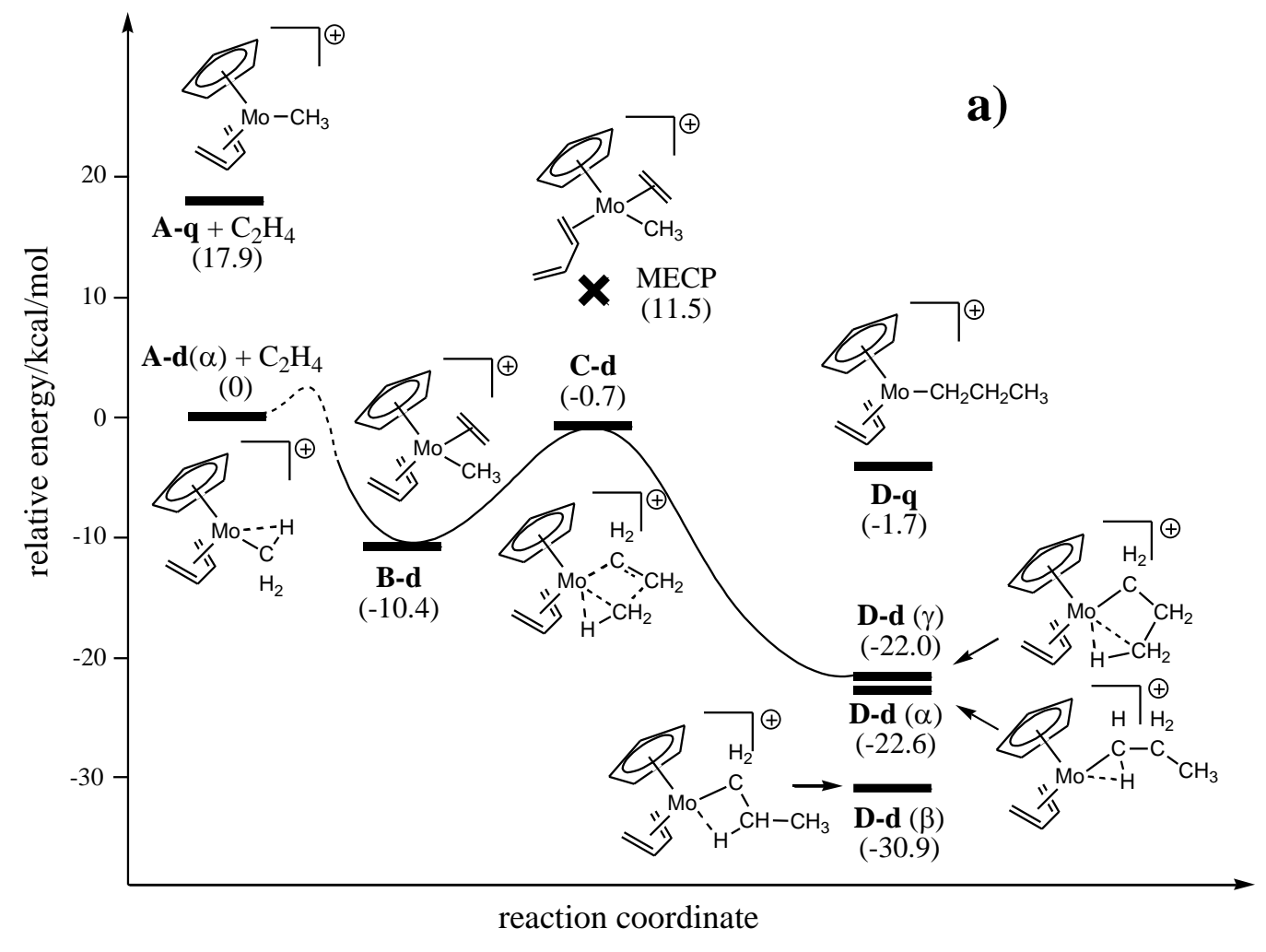




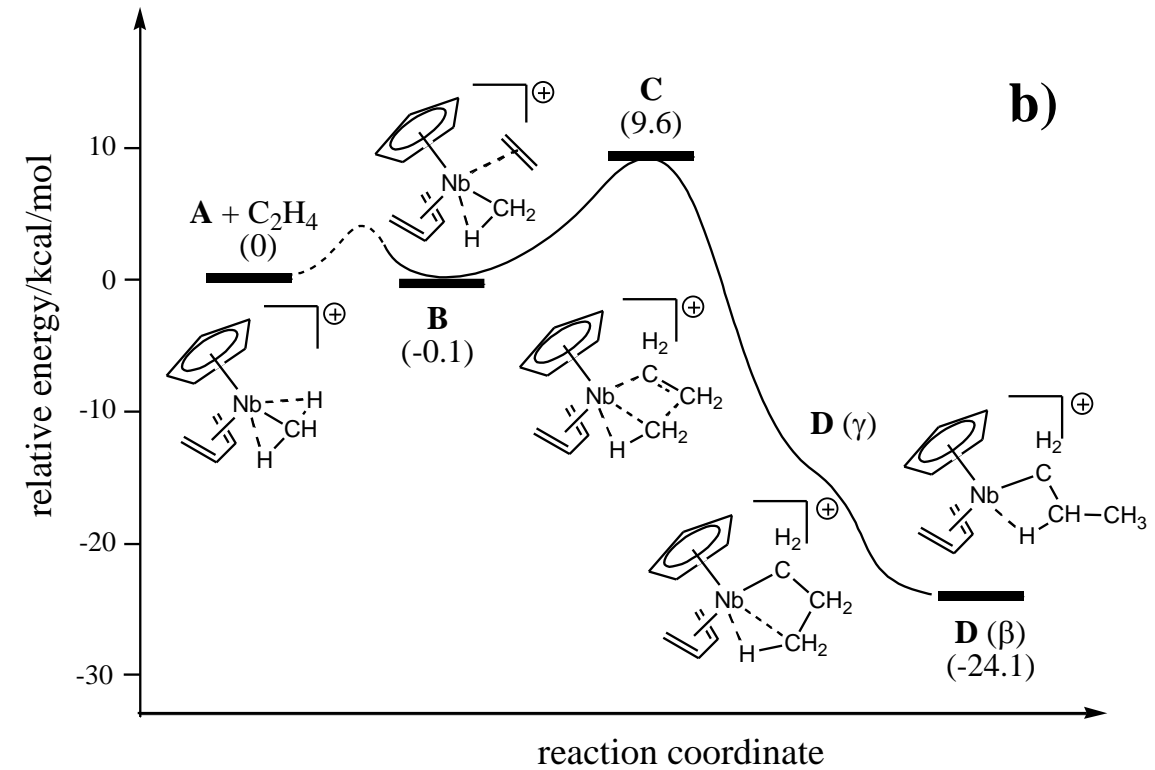

Figure 2a). In fact, this geometry is characterized by a $\eta^{2}$-coordinated diene ligand, a coordinated ethylene (Mo-C distances similar to those in $\mathbf{C}-\mathbf{d}$ ) and a coordinated $\mathrm{CH}_{3}$ group, with no indication of an incipient ethylene- $\mathrm{CH}_{3}$ interaction. Starting from this MECP geometry, optimization as a quartet leads to $\mathrm{CpMo}\left(\eta^{2}-\mathrm{C}_{4} \mathrm{H}_{6}\right)\left(\eta^{2}-\mathrm{C}_{2} \mathrm{H}_{4}\right)\left(\mathrm{CH}_{3}\right)$ with a relative energy of $4.5 \mathrm{kcal} / \mathrm{mol}$. It is quite unexpected that this quartet species is lower in energy relative to $\mathbf{A}-\mathbf{q}+$ free $\mathrm{C}_{2} \mathrm{H}_{4}$, indicating that two separate double bonds adjust better than a conjugated diene to the geometric preference of the spin quartet three-legged piano stool. At any rate, the above computational studies cast serious doubts on the intervention of spin quartet intermediates along the ethylene polymerization process catalyzed by $[\mathrm{CpMo}(\text { diene }) \mathrm{R}]^{+}$. To summarize, the $\left[\mathrm{CpMo}(\text { diene })\left(\eta^{2}-\mathrm{C}_{2} \mathrm{H}_{4}\right) \mathrm{R}\right]^{+}$intermediate leads to ethylene insertion along the spin doublet surface, while spin crossover to the quartet surface occurs at higher energy and leads to partial decoordination of the diene ligand. The calculations further indicate 
that the $[\mathrm{CpMo}(\text { diene }) \mathrm{R}]^{+}$species is kinetically competent to propagate the polyethylene chain growth with a high turnover frequency. The last conclusion appears consistent with the calculated chain propagation coordinate for the related $\mathrm{Nb}$ system (

Figure $2 \mathrm{~b})$, which shows an essentially identical barrier to insertion $(9.7 \mathrm{kcal} / \mathrm{mol}$ from $\mathbf{B}$ to C). It is important to emphasize that these calculations are carried out on sterically unhindered model compounds and hence are not directly comparable with the experimentally determined turnover frequencies. After submission of our manuscript, a more extensive computational study of the $[\mathrm{CpNb}(\text { diene }) \mathrm{R}]^{+}$- catalyzed ethylene polymerization has appeared in the literature. ${ }^{[83]}$ This study covers the insertion mechanism as well as the termination step and it is carried out with a variety of functionals and basis sets. However, it was limited to the niobium system. The results of our less extensive investigations agree with those of this more detailed study.

A few calculated structural features for the $\mathrm{Nb}$ system appear out of the ordinary and merit discussion. The optimized species $\mathbf{A}$ is not isostructural with the Mo system A-d( $\alpha)$. While the latter shows a single agostic interaction and the methyl $\mathrm{C}$ atom is displaced toward one side of the bisector plane of the $\mathrm{Cp}$ and butadiene ligands, see

a)

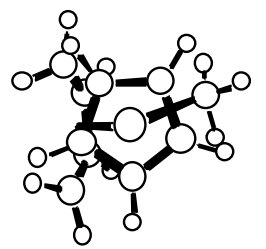

$A-d(\alpha)(M=M o)$ b)

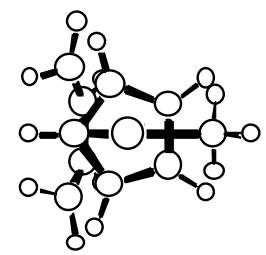

$A(M=\mathbf{N b})$

Figure 3a, the former shows a significant and equivalent distortion for two of the three methyl 
Table 5) and the methyl $\mathrm{C}$ atom lies on the bisector plane to afford a $\mathrm{C}_{\mathrm{S}}$ symmetric structure, see

a)

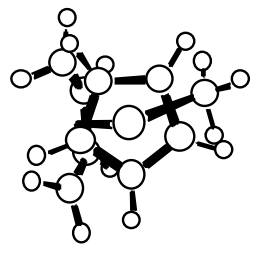

A-d $(\alpha)(M=M o)$ b)

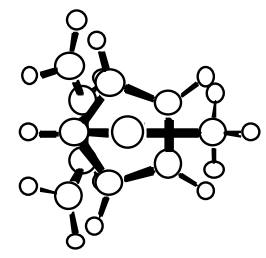

$A(M=\mathbf{N b})$

Figure $3 b$. It seems reasonable to attribute this difference to the availability of a second empty orbital on the $\mathrm{Nb}$ center, while this orbital is occupied by a single electron for Mo. This additional interaction possibly explains the lower energy of $\mathbf{A}$ relative to $\mathbf{B}$ and $\mathbf{C}$ for the $\mathrm{Nb}$ system vs the Mo system. It is interesting to remark that $\alpha$-agostic interactions were also calculated for $\left[\mathrm{Cp}_{2} \mathrm{Zr}\left(\mathrm{CH}_{3}\right)\right]^{+}$, but not for the isoelectronic $\mathrm{Cp}_{2} \mathrm{Sc}\left(\mathrm{CH}_{3}\right){ }^{[61]}$ An example of a double $\alpha$-agostic interaction was observed experimentally by single crystal neutron diffraction for compound $\mathrm{Mo}\left(\mathrm{CH}_{3}\right)_{2}\left(\mathrm{NC}_{6} \mathrm{H}_{3} \operatorname{Pr}_{2}{ }^{\mathrm{i}}-2,6\right)_{2} \cdot{ }^{[84]}$

a)

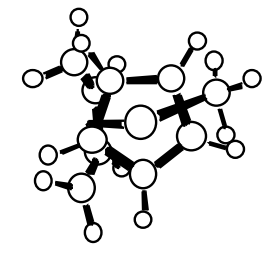

A-d $(\alpha)(M=M o)$ b)



Figure 3. Top views of the optimized geometries for $\left[\mathrm{CpM}\left(\mathrm{C}_{4} \mathrm{H}_{6}\right)\left(\mathrm{CH}_{3}\right)\right]^{+}(\mathrm{a}: \mathrm{M}=\mathrm{Mo} ; \mathrm{b}: \mathrm{M}=$ $\mathrm{Nb})$.

The same structure and energy for $\mathbf{B}$ has been obtained starting from an initial geometry which had been adapted from the optimized B-d $(\mathrm{M}=\mathrm{Mo})$, or by descending the reaction coordinate from the transition state $\mathbf{C}$, convincing us that this is the global minimum for this 
a)

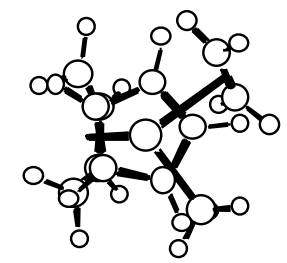

B-d (M = Mo) b)

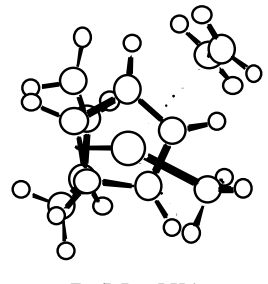

Figure 4. The first one is the presence of a single $\alpha$-agostic interaction for the methyl group in the $\mathrm{Nb}$ complex, while this is absent in the Mo complex. Like for $\mathbf{A}$, this difference is easily interpreted on the basis of the electronic difference between the two metals. Following ethylene coordination, only one metal orbital remains available for the agostic interactions. Thus, a single agostic interaction may be established when this orbital is empty $(\mathrm{Nb})$, and none when it is singly occupied (Mo). The second feature is a significantly weaker $\mathrm{M}-\mathrm{C}_{2} \mathrm{H}_{4}$ bond for $\mathrm{Nb}$. This phenomenon, also noticed by Laarson, ${ }^{[83]}$ appears again interpretable on the basis of the electronic difference. The same additional electron which blocks the formation of the agostic interaction for Mo also engages in a $\mathrm{Mo}-\mathrm{C}_{2} \mathrm{H}_{4}$ back bonding interaction which is absent for $\mathrm{Nb}$. This is clearly shown by the orbital diagrams in Figure 5. The half-occupied MO for the Mo system is essentially a metal $d_{x y}$ orbital, with a small in-phase participation of the ethylene $\pi^{*}$ combination which signals the back-bonding interaction. Interestingly, the corresponding empty $\mathrm{Nb}$ orbital (LUMO) shows a much smaller participation of the ethylene $\pi^{*}$ orbital and a much greater out-of-phase participation of the methyl $\mathrm{C} p$ orbital, corresponding to a $\pi$-type antibonding $\mathrm{Nb}-\mathrm{CH}_{3}$ interaction, i.e. the antibonding component of the $\mathrm{Nb}-\mathrm{H}-\mathrm{C}$ agostic interaction. Consistent with the presence of a 1-electron $\mathrm{Mo}_{2} \mathrm{C}_{2} \mathrm{H}_{4} \pi$ bonding interaction, the ethylene $\mathrm{C}-\mathrm{C}$ bond distance is greater for the Mo complex ( $c f$. Table 4 and 
Table 5). Figure 5 also shows the relative energies of the frontier orbitals for $\mathbf{B}(\mathrm{Nb})$ and $\mathbf{B}-\mathbf{d}$ (Mo). It can be noted, in particular, that the energy of the doubly occupied orbital, which is engaged in the M-diene back-bonding interaction, is higher for the less electronegative $\mathrm{Nb}$ system, as expected. Indeed, for all related pairs of complexes in Table 4 and 
Table 5, the external diene $\mathrm{C}-\mathrm{C}$ distances shortens on going from $\mathrm{Nb}$ to Mo, while the internal diene $\mathrm{C}-\mathrm{C}$ bond correspondingly lengthen.

a)

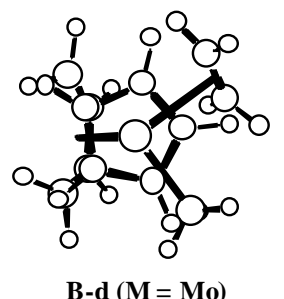

b)

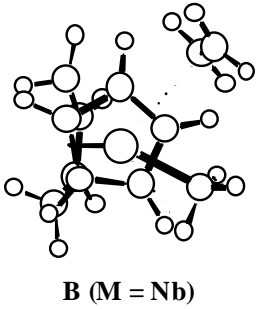

Figure 4. Top views of the optimized geometries for $\left[\mathrm{CpM}\left(\mathrm{C}_{4} \mathrm{H}_{6}\right)\left(\mathrm{C}_{2} \mathrm{H}_{4}\right)\left(\mathrm{CH}_{3}\right)\right]^{+}(\mathrm{a}: \mathrm{M}=\mathrm{Mo}$; $\mathrm{b}: \mathrm{M}=\mathrm{Nb})$

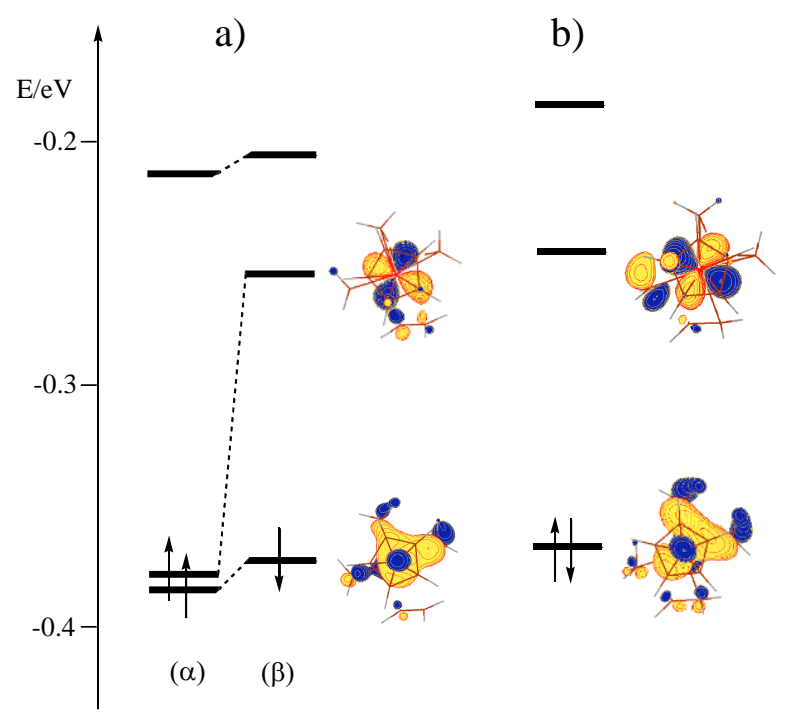

Figure 5. Energy diagram of the Kohn-Sham frontier molecular orbitals for structures $\left[\mathrm{CpM}\left(\mathrm{C}_{4} \mathrm{H}_{6}\right)\left(\mathrm{C}_{2} \mathrm{H}_{4}\right)\left(\mathrm{CH}_{3}\right)\right]^{+}(\mathrm{a}: \mathrm{M}=\mathrm{Mo} ; \mathrm{b}: \mathrm{M}=\mathrm{Nb})$. The contour diagrams shown for the Mo species are those of the $\beta$ spinorbitals. The corresponding $\alpha$ spinorbitals have an essentially identical shape.

The geometries of the transition states for the two metal complexes are very close ( $c f$. Table 
Table 5). In the transition state for the $\mathrm{Nb}$ system, the metal interacts more strongly with the propyl $\gamma-\mathrm{H}$ atom and with the propyl $\alpha-\mathrm{C}$ atom. Contrary to the Mo system, an energy minimum for a $\gamma$-agostic propyl complex, $\mathbf{D}(\gamma)$, could not be located with $\mathrm{Nb}$. Starting from either an adapted geometry from optimized D-d( $\gamma)(\mathrm{M}=\mathrm{Mo})$ or descending the reaction coordinate from the optimized $\mathbf{C}$, led to the same $\beta$-agostic product. Obviously, even if a local minimum for a $\gamma$ agostic structure should exist, its rearrangement barrier to the $\beta$-agostic product must be very small. The optimized geometries of the $\beta$-agostic propyl products are nearly identical for the $\mathrm{Nb}$ and

Mo

systems

(cf.

Table

4

and 
Table 5). The $\alpha$-agostic complex has not been optimized for $\mathrm{Nb}$. The olefin insertion process [B to $\mathbf{D}(\boldsymbol{\beta})$ ] is exothermic by $24 \mathrm{kcal} / \mathrm{mol}$ for $\mathrm{Nb} v s .20 .5 \mathrm{kcal} / \mathrm{mol}$ for Mo.

In conclusion, the additional metal electron for the Mo complex does not play any significant role in altering the enthalpic barrier to the olefin insertion process. However, the low polarity of the $\mathrm{Mo}_{-} \mathrm{CH}_{3}$ bond renders the activation step problematic. The most energetically costly step consists of the ion separation to afford the active 15-electron species, which most likely exists as a $\beta$-agostic complex in the doublet spin state as this is the resting state of the chain propagation process.

\section{Discussion}

The present investigation has shown that the most important change for the catalytic activity of the $\mathrm{Cp} * \mathrm{M}\left(\eta^{4}\right.$-diene $)\left(\mathrm{CH}_{3}\right)_{2} / \mathrm{MAO}$ system on going from $\mathrm{Nb}$ to $\mathrm{Mo}$ is a decreased polarity of the $\mathrm{M}-\mathrm{CH}_{3}$ bond, affecting the activation step. On the other hand, the polymerization studies have shown that the Mo system is capable of generating an active site that leads to the formation of long and highly linear polymer chains. This site has in fact a higher turnover frequency than the related $\mathrm{Nb}$ active site. The more difficult activation step for Mo is born out by the DFT Mulliken analysis on the model $\mathrm{CpMo}\left(\eta^{4}\right.$-diene $)\left(\mathrm{CH}_{3}\right)_{2}$ precursors and by the calculated heterolytic Mo- $\mathrm{CH}_{3}$ BDE. The spin doublet 15 -electron $\left[\mathrm{CpMo}\left(\eta^{4} \text {-diene }\right) \mathrm{R}\right]^{+}$species appears to be kinetically competent to carry out the chain propagation process. Therefore, it seems that this $\mathrm{Mo}$ (III) system is a potentially attractive one provided that a different way to generate the 15-electron species is found and we are actively working in this direction. Given the established steric effect on the activation step, ${ }^{[43]}$ derivatives based on more encumbering cyclopentadienyl rings such as $\mathrm{C}_{5} \mathrm{HPr}_{4}{ }_{4}$ or $\mathrm{C}_{5} \mathrm{Ph}_{5}$ are current synthetic targets.

The formation of high-density polyethylene indicates that this system does not favour the chain transfer process, which would require a $\beta-\mathrm{H}$ elimination, a $\beta-\mathrm{H}$ transfer, or a transmetallation to aluminum. The absence of transmetallation may be attributed to the 
covalence of the Mo- $\mathrm{R}$ bond ( $\mathrm{R}$ = growing polymer chain), which is the same cause of the difficult activation process. The unfavorable $\beta$-H elimination and transfer processes can be rationalized by the low availability of the metal lone pair, which is heavily engaged in backbonding with the diene ligands, even though to a lesser extent than for the Group $5(\mathrm{Nb}, \mathrm{Ta})$ congeners. This back-bonding interaction may in fact be the primary cause, more so than the agostic interaction, for the adoption of a doublet ground state by the 15 -electron $\left[\mathrm{CpMo}\left(\eta^{4}-\right.\right.$ diene) $\mathrm{R}]^{+}$. The argument is illustrated in an oversimplified but, we believe, qualitatively correct fashion in Scheme 3. In the 15 -electron $\left[\mathrm{CpMo}\left(\eta^{4} \text {-diene }\right) \mathrm{R}\right]^{+}$complex, six metal orbitals are used to receive the electrons from the ligands, thus 3 metal orbitals remain available to accommodate the metal electrons and to establish the back-bonding interactions with the ligands. In the doublet form I, one of these three orbitals is doubly occupied, one is half occupied, and the third one is empty. While the empty orbital may be profitably used to establish the agostic interaction, the doubly occupied orbital can maximize the back-bonding interaction with the diene ligand. This is emphasized in Scheme 3 by including the metallapentene limiting form where the doubly occupied metal orbital has now become fully involved in the $\sigma$ interaction scheme. ${ }^{[85]}$ The heavy involvement of the two metal electrons in the M-diene back-bonding interaction makes them unavailable to trigger a chain transfer during the chain growth process by the $\beta$-H elimination pathway, while the unpaired electron in the other metal orbital is evidently insufficient to cause the same phenomenon. Several examples of stable/inert $\beta$-H-containing alkyl compounds where the available metal electrons are all unpaired are known. ${ }^{[78]}$ Thus, this additional electron is located in an inactive orbital and plays no apparent role during the chain propagation mechanism.

Scheme 3 


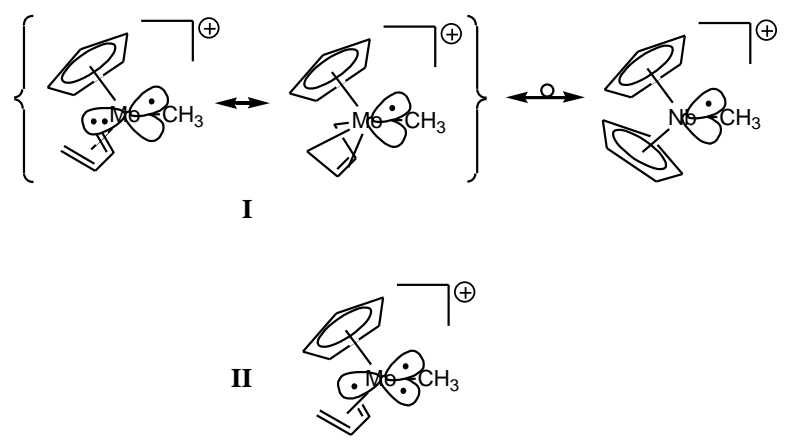

In the quartet form II, neither the agostic interaction, nor the back-bonding interaction to the diene ligand can be as effective. Indeed, the Mo-C(diene) distances increase dramatically on going from the doublet to the quartet species (e.g. for species $\mathbf{A}$ the average distance to the lateral $\mathrm{C}$ atoms increases from 2.25 to $2.63 \AA$, and that to the internal $\mathrm{C}$ atoms from 2.37 to $2.48 \AA$ ), and the diene $\mathrm{C}-\mathrm{C}$ bonding pattern manifests a much weaker transfer of electron density from the metal to the diene Huckel-type $\pi 3$ orbital. Therefore, the $\pi$-acidic nature of the diene ligand is the major cause forcing electron pairing in the 15 -electron $\left[\mathrm{CpMo}\left(\eta^{4} \text {-diene }\right) \mathrm{R}\right]^{+}$species. Other organometallic 15-electron $\mathrm{Mo}$ (III) species do adopt spin quartet ground states, e.g. $\left[\left(\mathrm{C}_{5} \mathrm{Ph}_{5}\right)_{2} \mathrm{Mo}\right]^{+}$and $\mathrm{Mo}\left(\mathrm{SC}_{6} \mathrm{H}_{3} \mathrm{Mes}_{2}-2,6\right)_{3},{ }^{[86,87]}$ the latter having one of the mesityl groups $\eta^{6}-$ bonded to the metal center. Furthermore, species $\mathrm{CpMoCl}_{2}\left(\mathrm{PR}_{3}\right)$, whose isolation did not prove possible, ${ }^{[88]}$ would also adopt a spin quartet ground state according to DFT calculations. ${ }^{[74-76]}$

On the basis of this simple model, we predict that the replacement of the diene with a less $\pi$ acidic ligand should stabilize the quartet ground state of a putative $\left[\mathrm{CpMoL}_{2} \mathrm{R}\right]^{+}$intermediate, possibly leading to more efficient polymerization catalysts. Previous investigations in our laboratory have shown that compound $\mathrm{CpMo}\left(\mathrm{PMe}_{3}\right)_{2}\left(\mathrm{CH}_{3}\right)_{2}$ is thermally unstable. $\left.{ }^{[89,} 90\right]$ However, a large variety of other ligands are at our disposal and future work in our laboratory will also be carried out in this direction. 


\section{Experimental}

General procedures. All reactions involving air- and moisture-sensitive organometallic compounds were carried out in a Jacomex glove box or by the use of standard Schlenck techniques under an argon atmosphere. Toluene and diethyl ether were purified by distillation under argon after drying over sodium benzophenone ketyl. THF was dried over sodium benzophenone ketyl and then over $\mathrm{Na} / \mathrm{K}$ alloy. Pentane was dried over sodium. The IR spectra were recorded on a Bruker IFS $66 \mathrm{~V}$ spectrophotometer with $\mathrm{NaCl}$ optics. EPR measurement were carried out at the X band microwave frequency on a Bruker ESP 300 spectrometer, equipped with a ER 4111 VT unit. The spectrometer was calibrated with DPPH (g =2.0037). EPR spectra simulations and fittings were carried out with WinSim. ${ }^{[91]}$ Cyclic voltammograms were recorded with an EG\&G 362 potentiostat connected to a Macintosh computer through MacLab hardware/software. The electrochemical cell is a locally modified Schlenk tube. The cell is fitted with a Pt counterelectrode, a $\mathrm{Ag} / \mathrm{AgCl}$ reference electrode and a Pt working electrode. $\mathrm{Bu}_{4} \mathrm{NPF}_{6}$ was used as supporting electrolyte at a concentration of $0.1 \mathrm{M}$. All potentials are reported vs. the $\mathrm{Cp}_{2} \mathrm{Fe} / \mathrm{Cp}_{2} \mathrm{Fe}^{+}$couple which was introduced under argon into the cell at the end of each measurement. Elemental analyses were performed with a Fisons EA 1108 apparatus. The polyethylene GPC analyses were carried out with a Polymer Labs mod. 210 apparatus equipped with a 4*TSK gel GM-H6 column. The polyethylene DSC analyses were carried out with a Perkin Elmer mod. DSC7 instrument. 2-Methylbuta-1,3-diene and 2,3-dimethylbuta-1,3-diene (Aldrich Chemical Co.) were degassed and stored on $\mathrm{A} 4$ molecular sieves before use. $\mathrm{CH}_{3} \mathrm{MgBr}$ (3.0 $\mathrm{M}$ in $\left.\mathrm{Et}_{2} \mathrm{O}\right)$ and $\mathrm{MAO}(10 \% \mathrm{w} / \mathrm{w}$ in toluene) (Aldrich Chemical Co.) were used as received. Compounds $\left[\mathrm{Cp}^{*} \mathrm{MoCl}_{2}\right]_{2}{ }^{[92]}$ and $\mathrm{CpMo}\left(\eta^{4}\right.$-diene $) \mathrm{X}_{2}\left(\mathrm{X}=\mathrm{Cl}, \mathrm{CH}_{3}\right.$; diene = buta-1,3-diene, 2methylbuta-1,3-diene, 2,3-dimethylbuta-1,3-diene $)^{[37]}$ were synthesized according to the literature procedures.

Synthesis of $\mathrm{Cp} * \mathrm{Mo}\left(\eta^{4}\right.$-diene $) \mathrm{Cl} 2$. (a) Diene $=2$-methylbuta-1,3-diene, 1. To a suspension of $\left[\mathrm{Cp}^{*} \mathrm{MoCl}_{2}\right]_{2}(176 \mathrm{mg}, 0.29 \mathrm{mmol})$ in $30 \mathrm{~mL}$ of THF was added 2-methylbuta- 
1,3-diene ( $72 \mu \mathrm{L}, 0.72 \mathrm{mmol}$ ). The mixture was warmed to $70^{\circ}$ for $4 \mathrm{~h}$, during which time the suspension turned into a red-brown solution. After evaporation of the solvent to ca. half volume, the product 1 was precipitated by addition of pentane $(10 \mathrm{~mL})$. The compound was recovered by filtration, washed with pentane $(2 \times 7 \mathrm{~mL})$ and dried under vacuum. Yield $162 \mathrm{mg}(74 \%)$. Anal. Calcd. for $\mathrm{C}_{15} \mathrm{H}_{23} \mathrm{Cl}_{2} \mathrm{Mo}$ : C, 48.67; H, 6.26. Found: C, 48.98, H, 6.67. EPR (THF, $20^{\circ} \mathrm{C}$ ): singlet with Mo satellites, $\mathrm{g}=1.997$; $\mathrm{a}_{\mathrm{Mo}}=37.8 \mathrm{G} . \quad \mathrm{MS}(\mathrm{EI}, 70 \mathrm{eV}): \mathrm{m} / \mathrm{z} 371\left([\mathrm{M}]^{+}\right.$, $\mathrm{MoCl}_{2}$ pattern, 5.2\%), $336\left(\left[\mathrm{Cp} * \mathrm{MoCl}\left(\mathrm{C}_{5} \mathrm{H} 8\right)\right]^{+}, \mathrm{MoCl}\right.$ pattern, 21.5\%), $303\left(\left[\mathrm{Cp}^{*} \mathrm{MoCl}_{2}\right]^{+}\right.$, $\mathrm{MoCl}_{2}$ pattern, 67.4\%), $268\left([\mathrm{Cp} * \mathrm{MoCl}]^{+}\right.$, $\mathrm{MoCl}$ pattern, $\left.100 \%\right), 135\left(\left[\mathrm{C}_{10} \mathrm{H}_{15}\right]^{+}, 30 \%\right)$.

(b) Diene $=$ 2,3-dimethylbuta-1,3-diene, 2. By using a procedure identical to that described above for the isoprene derivative, compound 2 was synthesized starting from [Cp* $\left.\mathrm{MoCl}_{2}\right]_{2}$ (367 mg, $\left.0.62 \mathrm{mmol}\right)$ and 2,3-dimethylbuta-1,3-diene (175 $\left.\mu \mathrm{L}, 1.55 \mathrm{mmol}\right)$. Yield $336 \mathrm{mg}$ (72\%). Anal. Calcd. for $\mathrm{C}_{16} \mathrm{H}_{25} \mathrm{Cl}_{2} \mathrm{Mo}$ : C, 50.02; H, 6.56. Found: C, 49.63, H, 6.31. EPR (THF, $20^{\circ} \mathrm{C}$ ): singlet with Mo satellites, $\mathrm{g}=1.997$; a Mo $=37.8 \mathrm{G} . \mathrm{MS}(\mathrm{EI}, 70 \mathrm{eV}): \mathrm{m} / \mathrm{z} 385$ $\left([\mathrm{M}]^{+}, \quad \mathrm{MoCl}_{2}\right.$ pattern, 9.6\%), $350\left(\left[\mathrm{Cp}^{*} \mathrm{MoCl}\left(\mathrm{C}_{6} \mathrm{H}_{10}\right)\right]^{+}, \quad \mathrm{MoCl}\right.$ pattern, 5.2\%), 303 $\left(\left[\mathrm{Cp}^{*} \mathrm{MoCl}_{2}\right]^{+}, \mathrm{MoCl}_{2}\right.$ pattern, 100\%), $268\left([\mathrm{Cp} * \mathrm{MoCl}]^{+}, \mathrm{MoCl}\right.$ pattern, 90\%), $135\left(\left[\mathrm{C}_{10} \mathrm{H}_{15}\right]^{+}\right.$, $31 \%)$.

Synthesis of $\mathrm{Cp} * \mathrm{Mo}\left(\eta^{4}-\right.$ diene $)\left(\mathrm{CH}_{3}\right) 2$. (a) Diene = 2-methylbuta-1,3-diene, 3. During this procedure, all operations were conducted in the dark by wrappind all glassware with aluminum foil. To a precooled suspension of $1(150 \mathrm{mg}, 0.40 \mathrm{mmol})$ in diethyl ether $(30 \mathrm{~mL})$ at $-78^{\circ}$ was added $0.30 \mathrm{~mL}$ of $\mathrm{CH}_{3} \mathrm{MgBr}(3.0 \mathrm{M}$ diethyl ether solution, $0.90 \mathrm{mmol})$. The mixture was stirred and slowly allowed to raise in temperature. As this occurred, for formation of a white precipitate was observed, while the red-brown solid was consumed to yield a green solution. After further stirring at room temperature for $3 \mathrm{~h}$, the solvent was completely removed under reduced pressure and the residue was extracted with pentane $(2 \times 20 \mathrm{~mL})$. After filtration through Celite, the solution was evaporated to dryness leaving analytically pure 3. Yield $66 \mathrm{mg}$ (50\%). Anal. Calcd. for $\mathrm{C}_{17} \mathrm{H}_{29} \mathrm{Mo}: \mathrm{C}, 62.00 ; \mathrm{H}, 8.87$. Found: C, 61.83, H, 9.10. EPR 
(pentane, $-80^{\circ} \mathrm{C}$ ): multiplet with Mo satellites, $\mathrm{g}=2.013$; $\mathrm{a}_{\mathrm{Mo}}=33.3 \mathrm{G}$, $\mathrm{a}_{\mathrm{H}}=5.3(6 \mathrm{H})$; $\mathrm{a}_{\mathrm{H}}=6.0$ $(2 \mathrm{H}) ; \mathrm{a}_{\mathrm{H}}=5.3(2 \mathrm{H})$.

(b) Diene $=$ 2,3-dimethylbuta-1,3-diene, 4. By using a procedure identical to that described above for the isoprene derivative, compound 4 was synthesized starting from 2 (300 $\mathrm{mg}, 0.78 \mathrm{mmol})$ and $0.60 \mathrm{~mL}$ of $\mathrm{CH}_{3} \mathrm{MgBr}$ (3.0 M diethyl ether solution, $\left.1.80 \mathrm{mmol}\right)$. Yield 147 mg (55\%). Anal. Calcd. for $\mathrm{C}_{18} \mathrm{H}_{31} \mathrm{Mo}$ : C, 62.97; H, 9.10. Found: C, 62.79, H, 9.36. EPR (pentane, $-90^{\circ} \mathrm{C}$ ): multiplet with Mo satellites, $\mathrm{g}=2.012$; $\mathrm{a}_{\mathrm{Mo}}=33.0 \mathrm{G}$, $\mathrm{a}_{\mathrm{H}}=5.6(6 \mathrm{H})$; $\mathrm{a}_{\mathrm{H}}=5.9$ $(2 \mathrm{H}) ; \mathrm{aH}=5.1(2 \mathrm{H})$.

Ethylene polymerization runs. A standard procedure was used for all polymerization runs. The reactions were conducted at room temperature in a Büchi glass autoclave (for the low pressure reactions) or in a stainless steel Parr autoclave, both equipped with a mechanical stirrer. After an argon purge, toluene $(60 \mathrm{~mL})$ was introduced, followed by the appropriate amount (see Results and Discussion) of MAO. The reactor was then conditioned under ethylene (1 bar) for $30 \mathrm{~min}$ with stirring. A toluene solution $(10 \mathrm{~mL})$ of the appropriate molybdenum complex $(20$ $50 \mathrm{mg}$ ) was then added. The autoclave was then pressurized at the desired ethylene pressure and the reaction mixture was stirred for the required time (see Results and Discussion). After hydrolysis with $\mathrm{MeOH}$ containing $\mathrm{HCl}(10 \%)$ at reflux conditions for $1 \mathrm{~h}$, the polymer was collected by filtration, washed with $\mathrm{MeOH}$, and dried in an oven $\left(100^{\circ} \mathrm{C}\right)$ until constant weight.

Computational details. All calculations were performed using Gaussian94[93] or Gaussian98 ${ }^{[94]}$ on SGI Origin200 and Origin2000 workstations. The LANL2DZ basis set was employed to perform geometry optimizations with a DFT approach. The three parameter form of the Becke, Lee, Tang and Parr functional (B3LYP) ${ }^{[95]}$ was used in all cases. The energies reported for all open shell systems correspond to spin unrestricted B3LYP calculations (UB3LYP). The mean value of the first-order wavefunction, which is not an exact eigenstate of $S^{2}$ for unrestricted calculations, was considered suitable for the unambiguous identification of the spin state. Spin contamination was carefully monitored and the values of $<\mathrm{S}^{2}>$ for the UB3LYP systems at convergence were very close to the ideal values of 0.75 for doublets and 3.75 for 
quartets. The geometry of the minimum energy crossing point (MECP) was fully optimized by the method described in the literature, ${ }^{[96,97]}$ adapted for use with Gaussian.

Acknowledgement. We are grateful to the CNRS (Programme Catalyse pour l'Industrie et l'Environnement) and COST D17 (Working group on "Environmentally friendly catalysts for olefin polymerization") for funding, to the MENRT for a doctoral fellowship to ELG, to CINES for free computational time, to the Conseil Régional de Bourgogne for equipment funding, and to Dr. Francesco Menconi (Polimeri Europa) for the polyethylene GPC and DSC analyses and for helpful discussion.

Supporting Information Available: Cartesian coordinates for all B3LYP/LANL2DZ optimized structures ( 9 pages).

\section{References}

[1] H. H. Brintzinger, D. Fischer, R. Mülhaupt, B. Rieger, R. M. Waymouth, Angew. Chem., Int. Ed. Engl. 1995, 34, 1143-1170.

[2] W. Kaminsky, J. Chem. Soc., Dalton Trans. 1998, 1413-1420.

[3] H. G. Alt, J. Chem. Soc., Dalton Trans. 1999, 1703-1709.

[4] G. J. P. Britovsek, V. C. Gibson, D. F. Wass, Angew. Chem. Int. Ed. 1999, 38, 428-447.

[5] B. L. Small, M. Brookhart, A. M. A. Bennett, J. Am. Chem. Soc. 1998, 120, 4049-4050.

[6] B. L. Small, M. Brookhart, Macromolecules 1999, 32, 2120-2130.

[7] G. J. P. Britovsek, V. C. Gibson, B. S. Kimberley, P. J. Maddox, S. J. McTavish, G. A. Solan, A. J. P. White, D. J. Williams, Chem. Commun. 1998, 849-850.

[8] G. J. P. Britovsek, M. Bruce, V. C. Gibson, B. S. Kimberly, P. J. Maddox, S. Mastroianni, S. J. McTavish, C. Redshaw, G. A. Solan, S. Strömberg, A. J. P. White, D. J. Williams, J. Am. Chem. Soc. 1999, 121, 8728-8740. 
[9] K. H. Theopold, Eur. J. Inorg. Chem. 1998, 15-24, and references therein.

[10] V. R. Jensen, K. Angermund, P. W. Jolly, K. J. Børve, Organometallics 2000, 19, 403410.

[11] J. S. Rogers, X. Bu, G. C. Bazan, J. Am. Chem. Soc. 2000, 730-731.

[12] E. A. C. Brussee, A. Meetsma, B. Hessen, J. H. Teuben, Organometallics 1998, 17, 40904095.

[13] N. Desmangles, S. Gambarotta, C. Bensimon, S. Davis, H. Zahalka, J. Organometal. Chem. 1998, 562, 53-60.

[14] M. J. R. Brandsma, E. A. C. Brussee, A. Meetsma, B. Hessen, J. H. Teuben, Eur. J. Inorg. Chem. 1998, 1867-1870.

[15] D. Reardon, F. Conan, S. Gambarotta, G. Yap, Q. Wang, J. Am. Chem. Soc. 1999, 121, $9318-9325$.

[16] P. Witte, A. Meetsma, B. Hessen, Organometallics 1999, 18, 2944-2946.

[17] R. F. Jordan, Adv. Organomet. Chem. 1991, 32, 325-387.

[18] P. C. Mohring, N. J. Coville, J. Organometal. Chem. 1994, 479, 1-29.

[19] M. Bochmann, J. Chem. Soc., Dalton Trans. 1996, 255-270.

[20] G. Jeske, H. Lauke, H. Mauermann, P. N. Swepston, H. Schumann, T. J. Marks, J. Am. Chem. Soc. 1985, 107, 8091-8103.

[21] G. Jeske, L. E. Schock, P. N. Swepston, H. Schumann, T. J. Marks, J. Am. Chem. Soc. 1985, $107,8103-8110$.

[22] H. Mauermann, P. N. Swepston, T. J. Marks, Organometallics 1985, 4, 200-202.

[23] X. Olonde, A. Mortreux, F. Petit, J. Mol. Catal. 1993, 82, 75-82.

[24] J.-F. Pelletier, A. Mortreux, X. Olonde, K. Bujadoux, Angew. Chem., Int. Ed. Engl. 1996, $35,1854-1856$.

[25] Y.-X. Chen, P.-F. Fu, C. L. Stern, T. J. Marks, Organometallics 1997, 16, 5958-5963.

[26] F. Amor, A. Butt, K. E. du Plooy, T. P. Spaniol, J. Okuda, Organometallics 1998, 17, $5836-5849$. 
[27] T. Eberle, T. P. Spaniol, J. Okuda, Eur. J. Inorg. Chem. 1998, 237-244.

[28] G. Lanza, I. Fragalà, T. J. Marks, J. Am. Chem. Soc. 2000, 122, 12764-12777.

[29] K. Mashima, S. Fujikawa, A. Nakamura, J. Am. Chem. Soc. 1993, 115, 10990-10991.

[30] K. Mashima, S. Fujikawa, H. Urata, E. Tanaka, A. Nakamura, J. Chem. Soc., Chem. Commun. 1994, 1623-1624.

[31] K. Mashima, S. Fujikawa, Y. Tanaka, H. Urata, T. Oshiki, E. Tanaka, A. Nakamura, Organometallics 1995, 14, 2633-2640.

[32] J. Justino, M. M. Marques, S. Correia, A. R. Dias, F. Lemos, F. R. Ribeiro, Polymer Int. 1997, 44, 517-522.

[33] R. Choukroun, B. Douziech, C. Pan, F. Dahan, P. Cassoux, Organometallics 1995, 14, 4471-4473.

[34] G. A. Luinstra, L. C. Ten Cate, H. J. Heeres, J. W. Pattiasina, A. Meetsma, J. H. Teuben, Organometallics 1991, 10, 3227-3237.

[35] R. Schmid, T. Ziegler, Organometallics 2000, 19, 2756-2765.

[36] E. Le Grognec, R. Poli, L.-S. Wang, Inorg. Chem. Commun. 1999, 2, 95-96.

[37] E. Le Grognec, R. Poli, P. Richard, Organometallics 2000, 19, 3842-3853.

[38] L.-S. Wang, J. C. Fettinger, R. Poli, J. Am. Chem. Soc. 1997, 119, 4453-4464.

[39] R. Poli, J. Coord. Chem. B 1993, 29, 121-173.

[40] S. T. Krueger, R. Poli, A. L. Rheingold, D. L. Staley, Inorg. Chem. 1989, 28, 4599-4607.

[41] R. Poli, B. E. Owens, R. G. Linck, Inorg. Chem. 1992, 31, 662-667.

[42] P. Legzdins, W. S. McNeil, M. J. Shaw, Organometallics 1994, 13, 562-568.

[43] E. Y.-X. Chen, T. J. Marks, Chem. Rev. 2000, 100, 1391-1434, and references therein.

[44] L. Zhu, F.-C. Chiu, Q. Fu, R. P. Quirk, S. Z. D. Cheng, Physical Constants of Polyethylene, Wiley, New York, 1999.

[45] P. Legzdins, W. S. McNeil, K. M. Smith, R. Poli, Organometallics 1998, 17, 615-622.

[46] K. M. Smith, R. Poli, P. Legzdins, Chem. Commun. 1998, 1903-1904.

[47] R. Poli, K. M. Smith, Eur. J. Inorg. Chem. 1999, 877-880. 
[48] K. M. Smith, R. Poli, P. Legzdins, Chem. Eur. J. 1999, 5, 1598-1608.

[49] R. Poli, K. M. Smith, Eur. J. Inorg. Chem. 1999, 2343-2346.

[50] I. Cacelli, R. Poli, E. A. Quadrelli, A. Rizzo, K. M. Smith, Inorg. Chem. 2000, 39, 517524.

[51] R. Poli, K. M. Smith, Organometallics 2000, 19, 2858-2867.

[52] K. M. Smith, R. Poli, J. N. Harvey, Chem. Eur. J. 2001, 7, 1679-1690.

[53] H. Yasuda, A. Nakamura, Angew. Chem. Int. Ed. Engl. 1987, 26, 723-742.

[54] E. Le Grognec, R. Poli, P. Richard, R. Llusar, S. Uriel, submitted.

[55] D. D. Devore, F. J. Timmers, D. L. Hasha, R. K. Rosen, T. J. Marks, P. A. Deck, C. L. Stern, Organometallics 1995, 14, 3132-3134.

[56] M. Dahlmann, G. Erker, R. Fröhlich, O. Meyer, Organometallics 2000, 19, 2956-2967.

[57] W. A. King, S. Di Bella, G. Lanza, K. Khan, D. J. Duncalf, F. G. N. Cloke, I. L. Fragalà, T. J. Marks, J. Am. Chem. Soc. 1996, 118, 627-635.

[58] W. A. King, S. Di Bella, A. Gulino, G. Lanza, I. L. Fragalà, S. L. Stern, T. J. Marks, J. Am. Chem. Soc. 1999, 121, 355-366.

[59] G. Lanza, I. L. Fragalà, T. J. Marks, J. Am. Chem. Soc. 1998, 120, 8257-8258.

[60] T. K. Woo, L. Fan, T. Ziegler, Organometallics 1994, 13, 432-433.

[61] T. K. Woo, L. Fan, T. Ziegler, Organometallics 1994, 13, 2252-2261.

[62] T. Yoshida, N. Koga, K. Morokuma, Organometallics 1996, 15, 766-777.

[63] D. G. Musaev, R. D. J. Froese, M. Svensson, K. Morokuma, J. Am. Chem. Soc. 1997, $119,367-374$.

[64] D. G. Musaev, M. Svensson, K. Morokuma, S. Strömberg, K. Zetterberg, P. E. M. Siegbahn, Organometallics 1997, 16, 1933-1945.

[65] L. Deng, P. Margl, T. Ziegler, J. Am. Chem. Soc. 1997, 119, 1094-1100.

[66] L. Deng, T. K. Woo, L. Cavallo, P. M. Margl, T. Ziegler, J. Am. Chem. Soc. 1997, 119, 6177-6186.

[67] R. D. J. Froese, D. G. Musaev, K. Morokuma, J. Am. Chem. Soc. 1998, 120, 1581-1587. 
[68] L. Deng, T. Ziegler, T. K. Woo, P. Margl, L. Fan, Organometallics 1998, 17, 3240-3253.

[69] P. Margl, L. Deng, T. Ziegler, Organometallics 1998, 17, 933-946.

[70] P. Margl, L. Deng, T. Ziegler, J. Am. Chem. Soc. 1998, 120, 5517-5525.

[71] E. A. H. Griffiths, G. J. P. Britovsek, V. C. Gibson, I. R. Gould, Chem. Commun. 1999, 1333-1334.

[72] L. Deng, P. Margl, T. Ziegler, J. Am. Chem. Soc. 1999, 121, 6479-6487.

[73] M. S. W. Chan, K. Vanka, C. C. Pye, T. Ziegler, Organometallics 1999, 18, 4624-4636.

[74] I. Cacelli, D. W. Keogh, R. Poli, A. Rizzo, New J. Chem. 1997, 21, 133-135.

[75] I. Cacelli, D. W. Keogh, R. Poli, A. Rizzo, J. Phys. Chem. A 1997, 101, 9801-9812.

[76] K. M. Smith, R. Poli, J. N. Harvey, New J. Chem. 2000, 24, 77-80.

[77] R. Poli, Acc. Chem. Res. 1997, 30, 494-501.

[78] R. Poli, Chem. Rev. 1996, 96, 2135-2204.

[79] D. V. Khoroshun, D. G. Musaev, T. Vreven, K. Morokuma, Organometallics 2001, 20, 2007-2026.

[80] See footnote 17 in ref. [63].

[81] P. Margl, L. Deng, T. Ziegler, Organometallics 1999, 18, 5701-5708.

[82] J. C. Hierso, M. Etienne, Eur. J. Inorg. Chem. 2000, 839-842.

[83] A. J. Sillanpää, K. E. Laasonen, Journal of the American Chemical Society 2001, 20, 1334-1344.

[84] J. M. Cole, V. C. Gibson, J. A. K. Howard, G. J. McIntyre, G. L. P. Walker, Chem. Commun. 1998, 1829-1830.

[85] It is to be noted that this doublet structure is isoelectronic with that of $\left[\mathrm{Cp} 2 \mathrm{Nb}\left(\mathrm{CH}_{3}\right)\right]^{+}$, just like $\left[\mathrm{CpNb}\left(\eta^{4} \text {-diene }\right) \mathrm{R}\right]^{+}$is isoelectronic with $\left[\mathrm{Cp}_{2} \mathrm{Zr}\left(\mathrm{CH}_{3}\right)\right]^{+}$. While compound $\mathrm{Cp}_{2} \mathrm{Nb}\left(\mathrm{CH}_{3}\right)_{2}$ was mentioned to be inactive as an ethylene polymerization catalyst (see ref. [31]), analogous derivatives with bulkier cyclopentadienyl rings have not been tested to the best of our knowledge.

[86] W. Hübel, R. Merényi, J. Organomet. Chem. 1964, 2, 213-221. 
[87] B. S. Buyuktas, M. M. Olmstead, P. P. Power, Chem. Commun. 1998, 1689-1690.

[88] F. Abugideiri, D. W. Keogh, H.-B. Kraatz, R. Poli, W. Pearson, J. Organomet. Chem. 1995, 488, 29-38.

[89] R. Poli, S. T. Krueger, F. Abugideiri, B. S. Haggerty, A. L. Rheingold, Organometallics 1991, 10, 3041-3046.

[90] E. Le Grognec, R. Poli, P. Richard, J. Chem. Soc., Dalton Trans. in press.

[91] D. R. Duling, P.E.S.T., v. 0.96, National Institute of Environmental Health Sciences, Research Triangle Park, NC, 1996.

[92] F. Abugideiri, R. Poli, in Synthetic Methods of Organometallic and Inorganic Chemistry (Herrmann/Brauer), Vol. 8 (Ed.: W. A. Herrmann), Georg Thieme Verlag, Stuttgart, 1997, pp. 102-103.

[93] M. J. Frisch, G. W. Trucks, H. B. Schlegel, P. M. W. Gill, B. G. Johnson, M. A. Robb, J. R. Cheeseman, T. A. Keith, G. A. Petersson, J. A. Montgomery, K. Raghavachari, M. A. Al-Laham, V. G. Zakrzewski, J. V. Ortiz, J. B. Foresman, J. Cioslowski, B. B. Stefanov, A. Nanayakkara, M. Challacombe, C. Y. Peng, P. Y. Ayala, W. Chen, M. W. Wong, J. L. Andres, E. S. Replogle, R. Gomperts, R. L. Martin, D. J. Fox, J. S. Binkley, D. J. Defrees, J. Baker, J. P. Stewart, M. Head-Gordon, C. Gonzales, J. A. Pople, Gaussian 94 (Revision E.1), Gaussian Inc., Pittsburgh, PA, 1995.

[94] M. J. Frisch, G. W. Trucks, H. B. Schlegel, G. E. Scuseria, M. A. Robb, J. R. Cheeseman, V. G. Zakrzewski, J. Montgomery, J. A., R. E. Stratmann, J. C. Burant, S. Dapprich, J. M. Millam, A. D. Daniels, K. N. Kudin, M. C. Strain, O. Farkas, J. Tomasi, V. Barone, M. Cossi, R. Cammi, B. Mennucci, C. Pomelli, C. Adamo, S. Clifford, J. Ochterski, G. A. Petersson, P. Y. Ayala, Q. Cui, K. Morokuma, D. K. Malick, A. D. Rabuck, K. Raghavachari, J. B. Foresman, J. Cioslowski, J. V. Ortiz, A. G. Baboul, B. B. Stefanov, G. Liu, A. Liashenko, P. Piskorz, I. Komaromi, R. Gomperts, R. L. Martin, D. J. Fox, T. Keith, M. A. Al-Laham, C. Y. Peng, A. Nanayakkara, C. Gonzalez, M. Challacombe, P. M. W. Gill, B. Johnson, W. Chen, M. W. Wong, J. L. Andres, C. Gonzalez, M. Head- 
Gordon, E. S. Replogle, J. A. Pople, Gaussian 98, Revision A.7, Gaussian, Inc., Pittsburgh PA, 1998.

[95] A. D. Becke, J. Chem. Phys. 1993, 98, 5648-5652.

[96] J. N. Harvey, M. Aschi, H. Schwarz, W. Koch, Theor. Chem. Acc. 1998, 99, 95-99.

[97] J. N. Harvey, M. Aschi, Phys. Chem. Chem. Phys. 1999, 1, 5555-5563.

\section{Graphical Abstract}

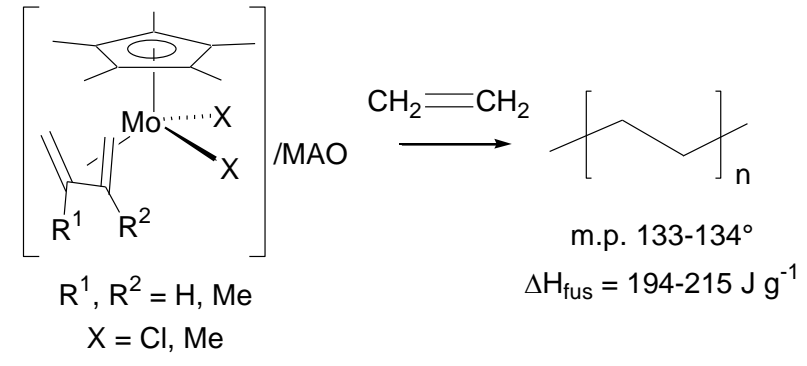

Complexes $\mathrm{Cp} * \mathrm{Mo}\left(\eta^{4}\right.$-diene $) \mathrm{X}_{2}($ diene $=$ isoprene or 2,3-dimethylbutadiene; $\mathrm{X}=\mathrm{Cl}$ or $\mathrm{CH}_{3}$ ) in combination with MAO yield highmolecular weight and highly linear polyethylene, but the activity is very low. Theoretical calculations in comparison with the corresponding $\mathrm{Nb}$ system illustrate the role played by the additional unpaired electron. 